\title{
Prognostic and Predictive Value of Cell Cycle Deregulation in Non-Small-Cell Lung Cancer
}

\author{
William Sterlacci ${ }^{\mathrm{a}} \quad$ Michael Fiegl $^{\mathrm{b}} \quad$ Alexandar Tzankov $^{\mathrm{c}}$ \\ anstitute of Pathology, Feldkirch Academic Hospital, Affiliation of the Innsbruck Medical University, Feldkirch, \\ and ${ }^{b}$ Division of Hematology and Oncology, Department of Internal Medicine, Innsbruck Medical University, \\ Innsbruck, Austria; ' Institute of Pathology, University Hospital Basel, Basel, Switzerland
}

\section{Key Words}

Non-small-cell lung cancer $\cdot$ Cell cycle $\cdot$ Deregulation

\begin{abstract}
Non-small-cell lung cancer (NSCLC) is among the most frequently diagnosed malignancy and a leading cause for cancer mortality worldwide. Despite various efforts, practical prognostic and predictive markers are still few. We review recent findings concerning the cell cycle in NSCLC and discuss prognostic and predictive aspects as well as the challenge of targeted therapeutic approaches. Deregulation of the cell cycle is a common event in NSCLC. Usually, several defects of cell cycle regulation are concomitant and have a cumulative adverse effect on prognosis. Therefore, analysis of a variety of interacting molecules is desirable for adequate deductions. Immunohistochemical interpretations should include the subcellular staining localization, since this can reflect the functional properties of a protein. Overexpression of cyclins, especially D-type cyclins, has repeatedly been associated with poor prognosis in NSCLC. Predictive data is less conclusive; however, loss of the expression of cyclin-dependent kinase inhibitors seems to correlate with sensitivity to antiproliferative drugs. Various inhibitors of Aurora kinases are currently being evaluated regarding their
\end{abstract}

potential as targeted therapies in NSCLC. In conclusion, the cell cycle offers several prognostic, predictive and therapeutic possibilities in NSCLC, many still developmental. Progress in this field has the potential to improve the current scenario for NSCLC patients.

Copyright $\odot 2012$ S. Karger AG, Basel

\section{Epidemiology and Risk Factors}

A recent overview on global cancer statistics showed that lung cancer was the most commonly diagnosed cancer, as well as the leading cause of cancer death (fig. 1) [1]. The association between cigarette smoking and lung cancer is one of the most thoroughly investigated medical issues, with compelling evidence indicating that smoking is the predominant causal factor for lung cancer [2-5]. Variations between countries and genders in the incidence of lung cancer largely reflect differences in the stage and degree of the tobacco epidemic $[6,7]$. Other known risk factors for lung cancer include exposure to occupational and environmental carcinogens such as asbestos, arsenic, radon and polycyclic aromatic hydrocarbons as well as preexisting lung diseases (e.g. tuberculosis and pneumonia) $[7,8]$.

\section{KARGER}

Fax +4161306 1234

E-Mail karger@karger.ch

www.karger.com
(C) 2012 S. Karger AG, Basel

1015-2008/12/0794-0175\$38.00/0

Accessible online at:

www.karger.com/pat
A. Tzankov

Institute for Pathology, University Hospital Basel

Schoenbeinstrasse 40

$\mathrm{CH}-4031$ Basel (Switzerland)

Tel. +41 61265 3229, E-Mail atzankov@uhbs.ch 


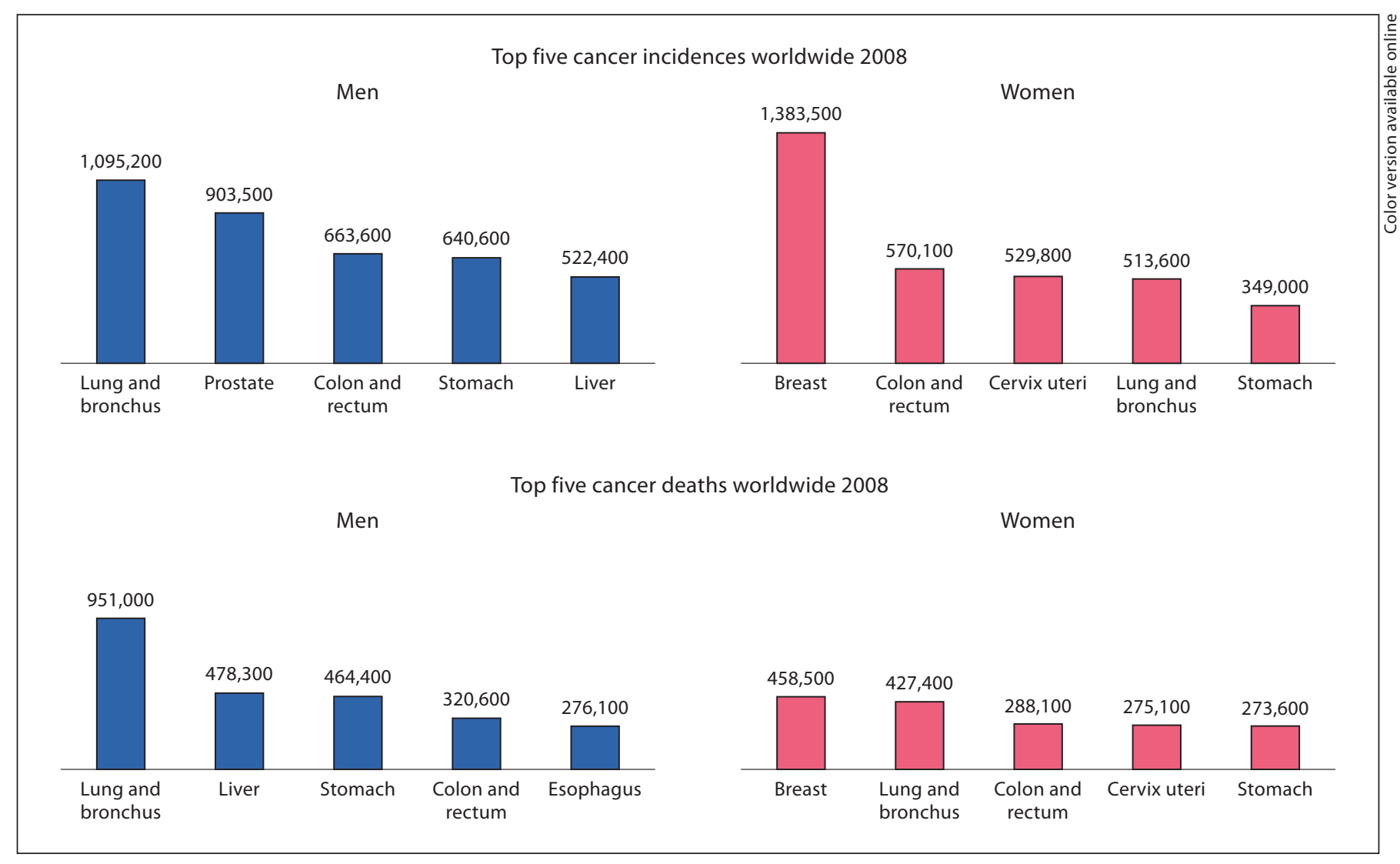

Fig. 1. Top 5 cancer incidences and deaths worldwide in 2008 [1].

\section{Histology}

Approximately $80 \%$ of all malignant lung tumors are classified as non-small-cell lung cancers (NSCLC) representing a heterogeneous group [9]. Around 20\% are small-cell lung carcinomas (SCLC) and less than $1 \%$ are nonepithelial tumors (e.g. lymphomas, sarcomas, germ cell tumors or melanomas). The most common NSCLC subtypes are squamous-cell carcinomas (SCC) and adenocarcinomas (ACA). SCC are predominantly linked to smoking, tend to arise centrally in the lung, have the capacity to grow to large sizes and are proportionally more common in male patients $[10,11]$. In contrast, ACA are usually found in the periphery of the lung and are proportionally more frequently diagnosed in women; although they are the most common type of lung cancer observed in nonsmokers, they have been increasingly associated with smoking in recent years [11-13]. ACA represent a very heterogeneous entity, obvious by the many morphological subtypes and various (often mutually exclusive) genetic alterations. This circumstance has recently prompted a new multidisciplinary classification approach for ACA [14]. SCLC have a greater potential to metastasize than other types and are generally associated with a very poor prognosis [15]. Almost all patients suffering from SCLC are current or former smokers [15].

\section{Symptoms, Prognosis and Management}

In the last decades, the overall prognosis for patients with lung cancer has remained dismal worldwide, with 5 -year survival rates averaging between 6 and 14\% for men and between 7 and 18\% for women [7]. The main reason for this poor outcome is that lung cancer is typically asymptomatic in the early stages of its development or may only cause nonspecific symptoms [16]; thus, the majority of lung cancer patients are diagnosed in a more advanced disease stage. 
Surgical resection is the treatment of choice for early localized tumors, whereas for advanced lung cancer treatment options become limited [16-19]. Trials involving platinum-based doublets have shown that adjuvant chemotherapy improves 5 -year overall survival by 8 to $15 \%$ in selected patients with resected stages II and IIIA NSCLC [20-22]. Adjuvant chemotherapy is currently still not routinely recommended for stage I disease, although trials have shown benefits regarding overall and relapsefree survival [23]. Taken together, some early-stage patients will have disease recurrence despite surgical resection with curative intent and other patients in an advanced stage may receive unnecessary adjuvant chemotherapy. These observations render NSCLC a very heterogeneous disease, calling for improved patient stratification regarding prognostication of survival time and prediction of treatment response.

Prognostic markers are defined as parameters (patient- or tumor-associated) that predict survival outcome independent of treatment. Predictive markers on the other hand are parameters for predicting treatment outcome, and may refer to response or survival. To date, the clinicopathologic staging system has been the standard for determining prognosis, although its value for the individual patient is questionable [24]. In ACA, additional mutation analysis of the epidermal growth factor receptor gene (EGFR), and - if unmutated (wild-type) - of the presence of the echinoderm microtubule-associated protein-like 4 (EML4) anaplastic lymphoma kinase 1 (ALK1) fusion gene or $A L K 1$ gene rearrangements, have therapeutic implications $[25,26]$. Patients with tumors harboring the EML4-ALK1 fusion gene or activating mutations in the EGFR gene are likely to respond to respective tyrosine kinase inhibitors (TKI) $[25,26]$. For approximately $40 \%$ of all ACA and for virtually all of the other histologic NSCLC subtypes, there are currently no predictive molecular parameters available [27]. To improve individualized treatment, many studies are focusing on the identification of prognostic and predictive molecular markers. A variety of oncogenes, tumor suppressor genes, cell cycle modulators and molecules related to tumor invasion, metastasis and angiogenesis have been reported in this regard [28-32].

Deregulation of the cell cycle can lead to uncontrolled cell proliferation and it has been found in many different human malignancies [33]. Molecules involved in the cell cycle have often been reported as prognostic markers and although the cell cycle also seems to offer potential anticancer targets, such strategies are not yet routinely established [34-37]. This review summarizes the importance

Cell Cycle in Non-Small-Cell Lung

Cancer

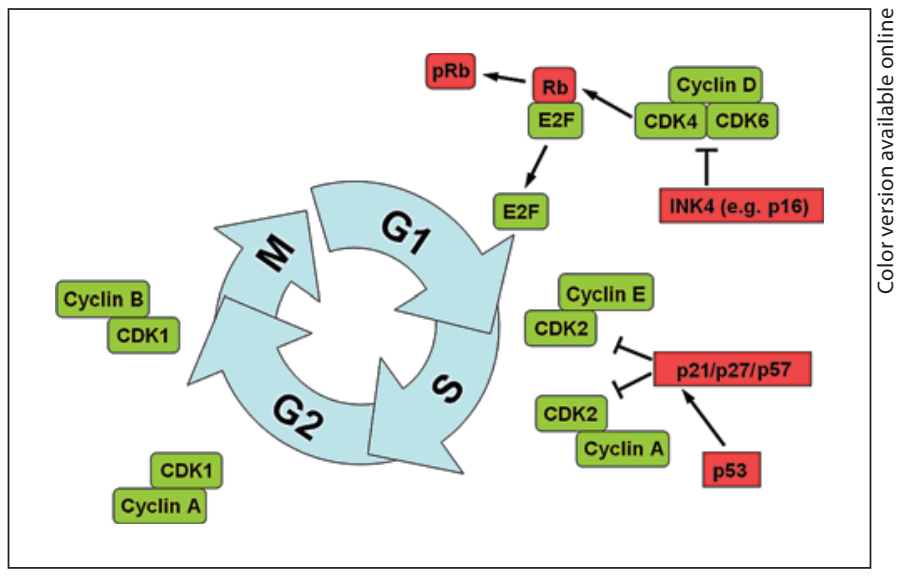

Fig. 2. Schematic of the major regulators of the cell cycle. Cyclin $\mathrm{D} /$ cyclin-dependent kinase 4 (CDK4) and cyclin D/CDK6 phosphorylate the $\mathrm{RB}$ which then releases $\mathrm{E} 2 \mathrm{~F}$ transcription factors leading to expression of cyclin E. Cyclin E/CDK2 causes transition from the $\mathrm{G} 1$ to the $\mathrm{S}$ phase. Cyclin A/CDK2 drives the cell cycle from the $\mathrm{S}$ phase to mitosis and cyclin $\mathrm{B} / \mathrm{CDK} 1$ conveys progression through the $\mathrm{M}$ phase. The inhibitory function of the CDK inhibitors (CKI) p16, p21, p27 and p57 is depicted by bars. Transcription of $\mathrm{p} 21$ is induced by $\mathrm{p} 53$.

and recent findings concerning the cell cycle in NSCLC and discusses the prognostic and predictive aspects as well as the challenge of therapeutic approaches.

\section{Cell Cycle Regulation}

The major regulators of the cell cycle are depicted in figure 2. The mammalian cell cycle is composed of 5 phases. Quiescent (nondividing) cells are in the G0 phase (interphase). In response to mitogenic signals, cells enter the G1 phase, which is characterized by an intracellular increase of D-type cyclins (D1, D2 and D3), resulting in cyclin D/cyclin-dependent kinase 4 (CDK4) and cyclin D/CDK6 complexes. These cyclin/CDK complexes initiate phosphorylation of the retinoblastoma proteins (RB), which leads to the release of E2F transcription factors, allowing expression of cyclin E [38]. Cyclin E binds and activates CDK2, further phosphorylating RB and causing the transition from the G1 to the $S$ phase [39]. The G1/S transition is also known as the restriction point, and is the critical point of the cell cycle. After passing this point, cells are committed to the next phases. In the $\mathrm{S}$ phase, a copy of the genetic material is produced, which must then be equally divided among the two daughter cells. CDK2 is activated by cyclin A to drive the cell cycle 


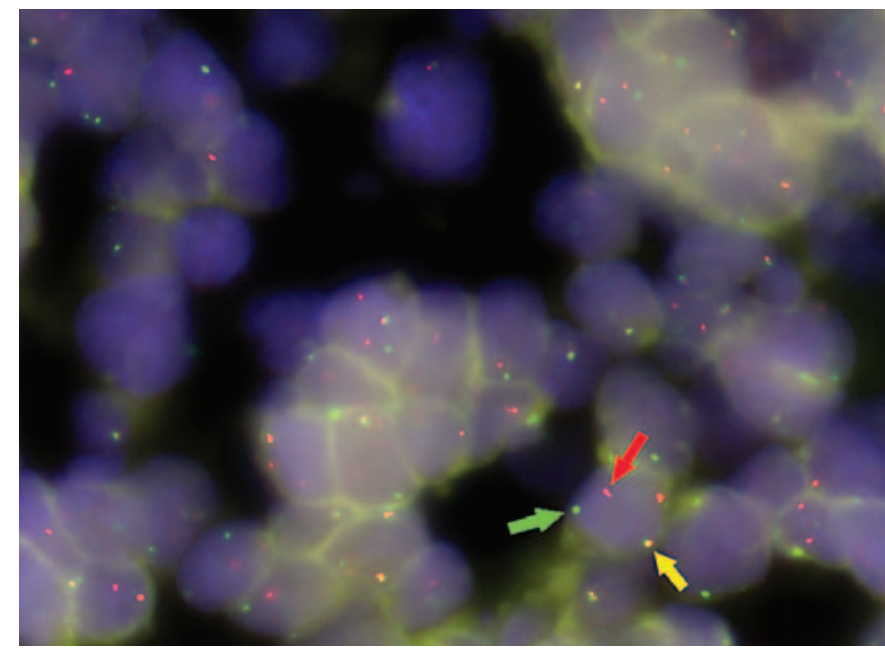

Fig. 3. Fluorescence in situ hybridization analysis of the Cyclin D1 (CCND1) gene with dual-colored break-apart probes flanking CCND1 (from Vysis/Abbott, Downers Grove, Ill., USA; CCND1: order No. 05J96-001). Note split red and green signals (red and green/black and gray arrows, in print and online, respectively) in a large-cell carcinoma corresponding to $C C N D 1$ gene rearrangements as well as 1 fused yellow signal (yellow/white arrow, in print and online, respectively) corresponding to the nonrearranged allele.

from the $S$ phase to mitosis, a stage termed G2 [33]. During the later $S$ phase and early G2 phase, the centrosomes are duplicated and form the poles of the mitotic spindle, which give rise to dynamic microtubules [40]. These events are controlled by CDK1 activated by cyclin A [41]. After disintegration of the nuclear envelope, cyclin $\mathrm{A}$ is degraded and cyclin $\mathrm{B} / \mathrm{CDK} 1$ complexes convey the progression through the $\mathrm{M}$ phase by promoting chromosomal condensation and assembly of the spindle apparatus [41]. The anaphase promoting complex or cyclosome (APC-C) degrades cyclin B and final segregation is facilitated [42].

Two families of CDK inhibitors (CKI) are known and play an important role in maintaining the cell cycle control [43]. The INK4 proteins, including INK4A (p16), INK4B (p15), INK4C (p18) and INK4D (p19), bind to CDK4 and CDK6, thus inhibiting their activation by Dtype cyclins. The WAF/CIP/KIP family of proteins includes WAF1/CIP1 (p21), KIP1 (p27) and KIP2 (p57), which form heterotrimeric complexes with the G1/S CDK. Proper progression through the cell cycle is assisted by checkpoints that detect defects during DNA synthesis and chromosome segregation and modulate CDK/ CKI activity. The cell cycle is then halted, providing time to repair such defects. If the damage is irreparable, programmed cell death or senescence is induced. An important pathway involved in preventing cells from entering the $S$ phase is the activation of the tumor suppressor gene $p 53$, which induces transcription of $\mathrm{p} 21$.

Accurate control of the cell cycle is essential for sustaining adequate cell proliferation. On the other hand, a characteristic of cancer cells is uncontrolled proliferation, independent of growth factors or growth inhibitory signals and tolerance towards DNA defects [44]. These features are acquired by the accumulation of various $\mathrm{mu}$ tations $[45,46]$. The importance of cell cycle deregulation in cancer is underlined by an increasing amount of related literature. Numerous studies show that among the many altered pathways involved in lung carcinogenesis, cell cycle deregulation is a frequent and critical occurrence [40, 47, 48]. Zhu et al. [48] presented an impressive graph depicting the amount of publications referring to various cell cycle-related molecules and their prognostic significance in NSCLC. p53, Bcl-2, Ki-67, cyclin D1 and $\mathrm{RB}$ were among the most extensively reported parameters. The role of other CKI and non-D-type cyclins (especially cyclins A and B) as well as CDK is less clear. Interestingly, the prognostic values differ among reports for most markers, which may be a reason for their lack of utility in everyday practice [48].

\section{Cyclins in NSCLC}

\section{D-Type Cyclins}

Cyclins are among the most thoroughly investigated molecules involved in the cell cycle in NSCLC. This is especially true for D-type cyclins, most likely because they are responsible for the transition from the G1 to the $S$ phase. Overexpression of D-type cyclins can shorten the G1 phase and reduce the cell dependency on mitogens [49-51]. Cyclin D1 is often both amplified/rearranged and overexpressed in NSCLC as well as in preinvasive tumorous lung lesions, indicating an early step in NSCLC carcinogenesis (fig. 3) $[37,52,53]$. The rate of gene amplification of the cyclin D1 locus (CCND1) has been reported at between 15 and 35\% in NSCLC [37, 52, 53]. This discrepancy can be explained by the amount of gene copies that were required for considering CCND1 as amplified, which varied between groups [37, 52, 53]. Overexpression is less variable and has been observed in around $40 \%$ of examined cohorts; importantly, the correlation between CCND1 gene amplification and increased cyclin D1 protein expression is obvious in 
NSCLC, and has also been found in other tumors [54, 55]. Although reports concerning cyclin D1 in NSCLC offer divergent conclusions regarding clinical outcome, most studies, and especially those published recently, link overexpression to worse prognosis $[37,56]$. An important means for obtaining more informative data is the combined analysis of multiple molecules known to interact with each other, which is superior to single-marker studies for the prediction of clinical outcome in NSCLC [37, 57]. For example, Burke et al. [58] analyzed 106 surgically resected, predominantly early-stage NSCLC with regard to the protein expression of cyclin D1, p21, RB, p16 and p53, as well as the mutational status of $p 53$. Overexpression of cyclin D1 and p21, loss of p16 and expression and mutation of $p 53$ were frequently observed [58]. No single marker was prognostically relevant, in contrast to certain combinations. Cyclin D1 overexpression in RB-negative tumors and cyclin D1 overexpression with either p53 expression or $p 53$ mutation were associated with significantly poorer prognosis [58]. In a similar study design, Myong [59] also observed that cyclin D1 overexpression, p16 loss and the inactivation of RB (by phosphorylation) are common in NSCLC. Furthermore, cyclin D1 overexpression correlated with p16 loss and RB inactivation and the overall survival of patients with the combination of cyclin D1 overexpression and loss of p16 tended to show a rapid decline [59]. Our own observations of a multitude of cell cycle markers in a comparably large cohort (405 cases) of surgically resected NSCLC revealed that cyclin D1 overexpression is associated with the overexpression of cyclin D3, p27 (nuclear), p21 and the loss of p16 $[36,37]$. The only independent prognostic parameters by multivariable analysis were the overexpression of cyclin D1 and the loss of p16, both indicating poor overall survival $[36,37]$. Taken together, these studies show various reproducible trends regarding NSCLC and cyclin (D)-associated cell cycle molecules: (1) deregulation of the G1 cell cycle phase is frequent and (2) it plays an important role in the carcinogenesis of NSCLC, (3) analysis of multiple functionally associated markers is more informative than single-parameter studies, (4) several defects of the cell cycle regulation are frequently concomitant and (5) they have a cumulative adverse effect on prognosis.

The special interest in cyclin D1 has led to the characterization of two alternative splice variants (cyclin Dla and $\mathrm{D} 1 \mathrm{~b}$ ) with different coding sequences that may be related to clinical outcome in NSCLC $[56,60]$. Difficulties in assessing this issue are due to the fact that cyclin D1 expression in NSCLC has mainly been analyzed immu-

Cell Cycle in Non-Small-Cell Lung Cancer nohistochemically $[37,60,61]$ and most available antibodies detect total cyclin D1 or the C-terminus of cyclin D1a [62]. In addition, cyclin D1b is usually present in quantities below the sensitivity of available assays [63]. Li et al. [63] used real-time reverse transcription polymerase chain reaction and immunohistochemistry (including a new specific antibody against cyclin D1b) to evaluate messenger RNA (mRNA) and protein expression levels of total cyclin D1 and the splice variants D1a and D1b, all of which were significantly upregulated in NSCLC when compared to nonmalignant lung tissue. They found that although the absolute expression levels of cyclin Dla were higher than those of cyclin D1b, the relative expression ratios of cyclin D1b mRNA between malignant and nonmalignant lung tissues were higher than those of cyclin D1a mRNA [63]. In contrast to cyclin D1a, cyclin D1b mRNA expression correlated with histological grade, lymph node metastasis, distant metastasis and tumor stage [63]. Increased mRNA and protein expression of cyclin D1b were also associated with poor survival, the latter even being an independent risk factor [63]. These results indicate that the splice variant cyclin D1b, in particular, contributes to tumorigenesis and may be a better prognostic marker than cyclin D1a or total cyclin D1 in NSCLC.

\section{Cyclins $E, A$ and $B$}

Cyclin E expression has commonly been associated with shorter overall survival for resectable NSCLC, although some studies found no prognostic value [37, 47]. As reported for cyclin D1, cyclin E is also often overexpressed in precursor lesions [64].

Compared to the numerous studies of regulators of the G1/S transition, cyclins of the S phase and G2/M transition are not well characterized in NSCLC [48]. Increased expression of cyclins A and B1 has been shown to correlate with poor tumor differentiation and squamous-cell histology in NSCLC [65-67]. Cooper et al. [65] recently reported frequent increases of cyclin $\mathrm{A}$ and $\mathrm{B} 1$ protein expression in stages I-II NSCLC (58.9 and 40.9\%, respectively) as well as in precursor lesions, compared to normal bronchial epithelia. They found that overexpression of cyclin B1 was significantly associated with poor prognosis on univariate, but not multivariate analysis; this was in contrast to others reporting cyclin B1 as an independent prognostic factor $[65,66]$. It is presently not clear if a cyclin B1-associated outcome is linked to a certain histological subtype, since this has been proposed for SCC as well as for ACA [65-67]. Cyclin A does not seem to be a prognostic marker for NSCLC, although this might be 
restricted to early tumor stages. Analysis of stages I-III found cyclin A to be associated with poorer survival [65, $68-71]$.

\section{Predictive Value of Cyclin Deregulation in NSCLC}

Although many reports concerning the prognostic significance of cyclins for NSCLC exist, information regarding predictive power is lacking. One study noted a downregulation of cyclin D1 by suppressing EGFR signaling in cell lines, suggesting that reduction of cyclin D1 expression may be a sensitive marker for the response to TKI [72]. They also found that cyclin D1 is overexpressed in lung cancer cells harboring mutant EGFR, which is in line with studies reporting that mutant EGFR preferentially activates AKT and STAT pathways, both implicated in CCND1 gene expression [73-77]. Flavopiridol, a drug that directly inhibits CDK4 and CDK6 and reduces the transcription of cyclin D1 by inhibiting CDK9 and CDK7, was shown to deplete cyclin D1 and induce substantial apoptosis in cell lines harboring EGFR mutations [78]. Importantly, TKI-resistant cells remained sensitive to flavopiridol, which may be a strategy to overcome/prevent resistance to EGFR inhibitors in patients with EGFRmutant NSCLC [72].

Cyclin/CDK complexes normally translocate to the nucleus and this is usually where the in situ immunohistochemical expression of cyclins is detected [37]. Many studies even disregard the cytoplasmic staining of cyclins, as it is considered nonspecific $[59,63]$. Interestingly, in some tumors including NSCLC, cyclin B1 is predominantly observed in the cytoplasm $[65,79,80]$. Cyclin B1/ CDK complexes are thought to remain in the cytoplasm due to DNA damage [81]. Therefore, it may be important to note the exact subcellular immunohistochemical staining pattern of cell cycle-related molecules, rather than disregard certain results. This issue is discussed in greater detail for CKI in the following section.

\section{Cyclin-Dependent Kinase Inhibitors}

$$
\text { p16 }
$$

The first tumor suppressor gene found in lung cancer was $R B$ [82]. Although loss of the RB protein (pRB) is reported in only around 15\% of NSCLC, most NSCLC have $\mathrm{RB}$ inactivation due to upstream regulatory defects [40, 83-85]. The CKI p16 inhibits cyclin D-dependent phosphorylation of the $\mathrm{pRB}$ by binding CDK4 and CDK6. Loss of p16 leads to phosphorylation of RB, releasing cell cycle inhibition and allowing uncontrolled
G1/S progress. Loss of p16 has been described for a variety of tumors including NSCLC and is usually associated with worse prognosis [86]. We (and others) have found loss of p16 expression to be an independent predictor of poor overall survival $[36,87,88]$. Major mechanisms of decreased p16 activity include gene deletion and hypermethylation of the CpG island promoter region, both being observed in NSCLC, whereas point mutations are rare [89-91]. Loss of p16 protein expression by immunohistochemistry is known to be an accurate method for detection of p16 gene inactivation events [91]. Our observations show that loss of p16 protein expression is frequent in NSCLC (63\%) and is an especially common feature of SCC compared to ACA, which is well in line with most previous studies addressing this issue $[59,92]$. Since most SCC are p16-negative, p16-positive SCC with a nondeleted $p 16$ gene might represent a distinct biological group. Considering that there may be a connection with human papilloma virus (HPV) infection (e.g. as is known for cervical cancer) in SCC expressing p16, we analyzed this group of tumors regarding a possible viral association [36]. Notably, nearly all of the patients were men (8/9) and the median overall survival time was 73 months compared to 44.7 months for the entire SCC cohort [36]. Tumor stage and grade, Ki-67 index and smoking status did not considerably differ [36]. We also performed immunohistochemistry using the Cytoactiv HPV L1 screening set (detection of HPV L1 capsid protein) as well as the Cytoactiv HPV L1 highrisk set (detection of L1 capsid protein of the high-risk HPV subtypes: 16, 18, 31, 33, 35, 39, 45, 56 and 58) (both from Cytoimmun Diagnostics GmbH, Pirmasens, Germany) [36]. No case showed a positive nuclear staining signal; thus, as expected, prognosis was indeed better, although no indication of HPV infection was apparent [36].

It has been shown that expression of p16 and cyclin D1 inversely correlate with each other, which reflects their functions in the cell cycle [59]. Since p16 inhibits CDK, which becomes active when bound to cyclin D1, loss of p16 protein can lead to elevated levels of cyclin D1 protein. Accordingly, the combination of cyclin D1 overexpression with loss of p16 has been considered useful to predict reduced overall survival prognosis [93].

DNA methylation plays an essential role in the maintenance of genomic stability; however, alterations in methylation patterns frequently occur in tumor cells [94]. Hypermethylation in the promoter regions of tumor suppressor genes are commonly associated with epigenetically mediated gene silencing [95]. In lung 
cancer, $p 16$ gene hypermethylation has been detected in 17 to $84 \%$ of cases in a smoking habit-dependent manner and may be a candidate marker for prediction and prognostication in NSCLC $[96,97]$. Studies have demonstrated that aberrant $p 16$ promoter hypermethylation is an early and critical event in the development of NSCLC [98]. Gene promoter hypermethylation has even been reported as a molecular marker for identifying healthy individuals at a high risk for cancer incidence since it has been observed in the serum and sputum of chronic smokers without clinical disease [99]. The importance of gene promoter hypermethylation lies in the possibility of epigenetic treatment options. Epigenetic changes involved in cancer development, unlike genetic changes, are reversible. Thus, patients with tumors harboring epigenetic alterations could benefit from treatment with demethylating agents. 5-Azacytidine is a demethylating agent that inhibits DNA methyltransferase 1 in replicating cells [100] and has recently been shown to prolong survival and improve quality of life in patients with myelodysplastic syndromes, while maintaining a favorable adverse-effect profile [101]. Prospective studies in NSCLC with promising results are ongoing [102]. A recent interim analysis of a phase II trial has reported that the combination of azacytidine and entinostat (a histone deacetylase 1 and 3 inhibitor) has a durable benefit in patients with advanced relapsed NSCLC [102]. So far, predictive markers for response to demethylating agents have not been established; however, the p16 methylation status may be a good candidate. The frequency and type (homozygous/heterozygous) of deletions of the 16 gene locus varies in the literature $[36,91]$. We recently performed a study examining the relationship between the protein expression, gene status and promoter hypermethylation of p16 [36]. Our data suggest that hypermethylation of the promoter region of $p 16$ is most likely the initial step toward loss of p16 function in NSCLC, followed by heterozygous deletion, which finally results in complete loss of protein expression; in our large series, we did not observe any cases of homozygous p16 deletion. Considering the possibility of early detection of hypermethylated gene regions, this data may lead to the identification of patient subgroups more likely to benefit from upcoming epigenetic treatment strategies.

The other members of the INK4 CKI family are not well characterized in NSCLC. p15 has been reported as frequently inactivated by homozygous deletions in NSCLC together with $p 16$ since both loci cluster together [103-105]. Methylation of the p15 gene has been found, but its effect on protein expression is poorly investigated [105-107]. p18 and p19 have been examined in only very few studies in NSCLC $[108,109]$. Polymorphisms have been found in the $p 18$ and $p 19$ genes, the former being associated with a decreased risk of death [109].

\section{p21}

p21, of the WAF/CIP/KIP family of CKI, is an inhibitor of several cell cycle phases, inhibiting cyclin D1/CDK4 and cyclin E/CDK2 complexes in the G1 phase and cyclin A/CDK2 complexes prior to the G2/S transition. Expression of p21 has been noted more commonly in earlystage NSCLC and seems to be a predictor of improved prognosis, although controversial reports exist [110-112]. For patients with nondetectable p21 and p16 expression, overall survival has been reported as significantly decreased compared to cases with loss of only one CKI [87], emphasizing the cumulative effect of cell cycle deregulation mechanisms on adverse outcome. Recently, promoter hypermethylation of $p 21$ was described in $30 \%$ of NSCLC and suggested as a critical mechanism for $p 21$ inactivation, especially in ACA [113]. Although DNA methylation was a frequent finding, loss of the $p 21$ gene product was more frequent, indicating that this epigenetic modification is not the main mechanism of p21 suppression [113]. Mutations of the $p 21$ gene have rarely been documented in malignancies [114]. Absence of p21 expression has been associated with resistance to cisplatin, one of the most potent anticancer agents and most effective systemic chemotherapies for NSCLC [115-117]. It has recently been shown that by increasing p21 expression through upregulation of $p 21$ gene expression in an NSCLC cell line, chemosensitivity to cisplatin was enhanced and cell growth was significantly inhibited in vivo and in vitro [118]. RNA-induced gene activation, a transcriptional gene activation phenomenon targeting gene promoter regions, was applied in this study, suggesting that this technique in combination with cisplatin-based chemotherapy may increase effectiveness, especially in drug-resistant tumors [118].

$\mathrm{p} 53$, often termed the guardian of the genome, is an important player in a main DNA damage response pathway [33]. Upon DNA damage, the tumor suppressor gene p53 is activated leading to transcriptional activation of $p 21$, thus preventing transition to the S phase [119]. In the presence of an altered form or loss of the p53 protein, $\mathrm{p} 21$ expression is drastically reduced or nondetectable [113]. Mutations of the $p 53$ gene are frequently found in NSCLC [120] and p53 nuclear immunoreactivity in tumors has been regarded as a surrogate marker for the presence of a 
p53 gene mutation, since mutant $\mathrm{p} 53$ protein has a longer half-life than the wild-type protein [121]. On the other hand, sensitivity and positive predictive value of immunohistochemistry for $p 53$ mutational status varies in the literature $[120,122]$. Generally, $p 53$ gene mutations and p53 protein overexpression are seen as weak prognostic markers of poorer outcome in NSCLC [123-126]. Conclusive predictive data concerning p53 in early-stage NSCLC treated with adjuvant chemotherapy is sparse. An Eastern Cooperative Oncology Group study randomly assigned completely resected stage II-IIIA NSCLC patients to receive adjuvant radiotherapy with or without etoposide plus cisplatin and found that $p 53$ gene mutation and p53 protein overexpression were neither prognostic of poorer survival nor predictive of a benefit from chemotherapy [127]. Another group, using tumor samples from JBR.10, a North American phase III intergroup trial that randomly assigned patients with completely resected stage IB and II NSCLC to receive 4 cycles of adjuvant cisplatin plus vinorelbine or observation alone, found that $\mathrm{p} 53$ protein overexpression was both prognostic for poorer survival and predictive of a greater survival benefit from adjuvant chemotherapy [120]. The observation that $\mathrm{p} 53$ protein expression rather than $p 53$ mutation is linked to a more aggressive clinical outcome has been speculated to be linked to the activation of oncogenic pathways regardless of $p 53$ mutational status leading to a stable (detectable) p53 protein [128-130]. The effect of $p 53$ mutations and aberrant p53 expression on the sensitivity of anticancer agents is contradictory $[120,129$, 131]. Sensitivity to cisplatin could possibly be caused by the absence of downstream activation of p21, leading to failure of DNA repair [131]. The retained ability to sufficiently repair DNA defects is believed to diminish the survival benefit from platinum-based chemotherapy in patients, whose tumors have high expression of the excision repair cross-complementation group 1 (ERCC1) protein [132]. The reported benefit from adjuvant chemotherapy in patients with low expression of ERCC1 leads to the conclusion that the best efficacy of platinum-based chemotherapy in NSCLC may be seen when ERCC1 expression is low and p53 expression is high and p21 inactive [120].

Due to the availability of tumor tissue, nearly all molecular studies are performed on surgically resected (i.e. generally early-stage) tumors. Patients in TNM tumor stage IIIA with metastasis to the ipsilateral mediastinal lymph nodes (N2) represent a heterogeneous group with regard to prognosis and treatment [133]. There is no consensus on the preferred management of patients with pre- operatively diagnosed N2 disease, although technically they are considered potentially resectable [134]. A study aiming to identify characteristics for deciding whether or not to perform surgery on patients with N2 disease focused on molecules of cell cycle regulation [133]. By examining the expression of proteins involved in the $\mathrm{RB}$ and p53 pathway, they found the loss of p16 and p21 to be independently associated with poorer overall survival [133]. Again, an additive functional cooperation between different cell cycle proteins was obvious, since patients with expression of both p16 and p21 had the best prognosis (compared to patients expressing only one or neither marker) [133]. They concluded that preoperative patients with $\mathrm{N} 2$ disease and expression of both p16 and p21 in their primary tumors are expected to have favorable postoperative survival outcome and may be candidates for primary resection [133]. Although the study limitations included a small sample size (61 cases) and a retrospective nature, the possibility of cell cycle regulators facilitating the decision process for surgical tumor resection arises. This is an intriguing approach, particularly considering the increasing use of minimal-invasive mediastinal lymph node tissue sampling (endobronchial ultrasoundguided, transbronchial needle aspiration).

\section{p27}

In addition to the cyclin/CDK complexes inhibited by p21, the CKI p27 is also able to inhibit cyclin D/CDK6. The importance of p27 is illustrated by knock-in mice expressing mutant $\mathrm{p} 27$ protein unable to bind and inhibit cyclin/CDK complexes. These mice have increased stem and progenitor cell populations as well as a variety of neoplasms [135]. Reduced protein levels of p27 have been reported in NSCLC and usually correlate with poor overall survival [136, 137]. The International Adjuvant Lung Cancer Trial demonstrated that adjuvant cisplatin-based chemotherapy improves the 5 -year survival rate of patients with completely resected NSCLC, a benefit that was confirmed by a pooled analysis of similar studies (survival improved at 5 years by an absolute value of 5\%) [20, 138]. To determine whether cell cycle regulators are of prognostic or predictive value for NSCLC patients, a study was performed analyzing tumor specimens from the International Adjuvant Lung Cancer Trial regarding protein expression of p16, p27, cyclins D1, D3 and E and Ki-67 [139]. It was shown that patients with p27-negative tumors benefited from cisplatin-based chemotherapy, whereas patients with p27-positive tumors did not [139]. Previous in vitro studies have indeed implicated p27 in drug resistance [140]. Since most anticancer agents pref- 
erentially target rapidly dividing cells, a low proliferation fraction is a major factor of drug resistance [141]. By preventing the G1/S transition, p27 halts the cell cycle, thus providing protection from antiproliferative drugs. Furthermore, p27 has an antiapoptotic effect; it inhibits the activation of procaspases and cytochrome $\mathrm{C}$ release, which may also contribute to a lack of chemosensitivity [142].

Generally, immunohistochemical detection p27 is associated with improved survival outcome and loss of p27 correlates with poor survival in a variety of cancer types $[143,144]$. On the other hand, studies involving lymphomas, in particular, have demonstrated that highly malignant neoplasms may also be associated with increased staining of p27 [145, 146]. High levels of p27 expression have also been found in some breast cancer cells [147]. An explanation for such conflicting data may be connected to the exact subcellular localization of p27 in tumor cells (fig. 4). Various manufacturers of antibodies directed against p27 depict positive results as a nuclear staining signal. Indeed some studies have only regarded p27 immunohistochemistry as positive when nuclear staining was observed, irrespective of cytoplasmic presence [57, 139]. This interpretation may not accurately reflect the biological importance of p27. As discussed, the INK4 CKI are frequently lost by deletion, promoter hypermethylation or mutation, events that are extremely rare in the p27 gene [148]. Nonetheless, p27 has been termed a tumor suppressor protein, since its inactivation has been linked to tumorigenesis [149]. Mechanisms of inactivation include loss of p27 expression as well as nuclear exclusion [150]. Degradation of the p27 protein by proteolysis is thought to be the major pathway for reducing its abundance [150]. In a first step, p27 is phosphorylated by cyclin E/CDK2 complexes (at threonine 187), followed by the ubiquitin-dependent proteasome degradation of p27 [151-155]. In this way, proteins intended for degradation are tagged with the small protein ubiquitin by ubiquitin ligases, resulting in polyubiquitin chains which are then bound by proteasomes leading to proteolysis of the target protein [151-155]. In response to mitogenic stimulation, the human kinase interacting stathmin may also phosphorylate $\mathrm{p} 27$, however at a different residue site (serine 10), leading to nuclear export of the p27 protein [156]. The protein kinase $\mathrm{B}(\mathrm{PKB}) / \mathrm{AKT}$ is responsible for $\mathrm{p} 27$ phosphorylation at threonine 157, inducing cytoplasmic retention [157]. PKB/AKT also phosphorylates the forkhead transcription factor Afx, thus keeping it in the cytoplasm and preventing $p 27$ gene transcription $[158,159]$. Cytoplasmic localization of p27 does not result in its degrada-

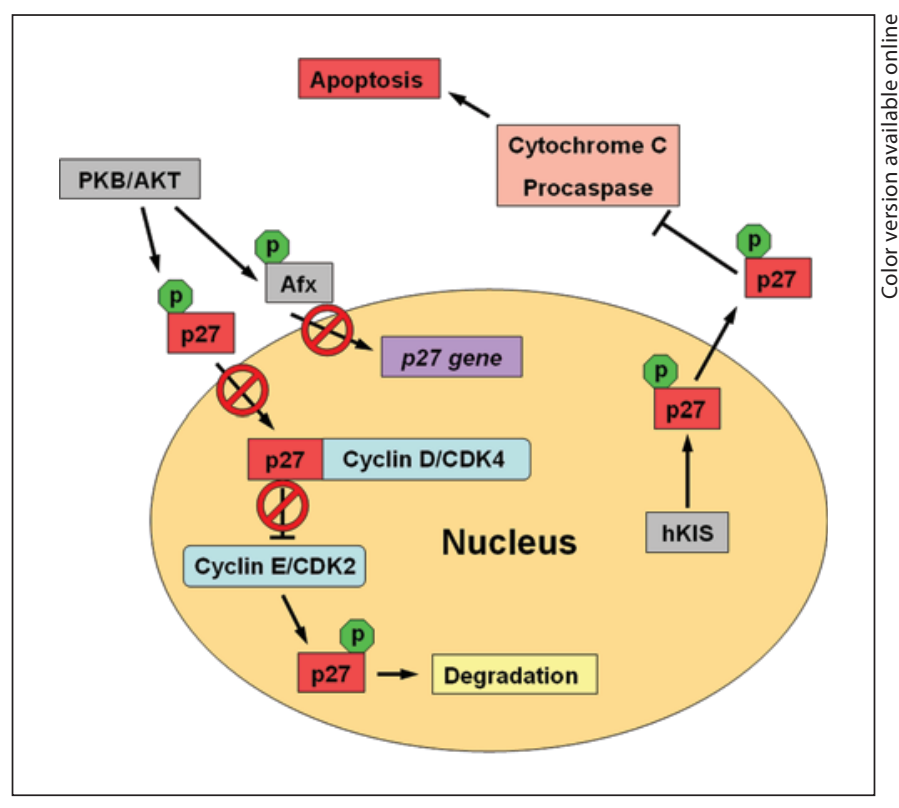

Fig. 4. Schematic of the major 27 functions. In the nucleus cyclin $\mathrm{D} /$ cyclin-dependent kinase 4 (CDK4) complexes titrate p27 away from cyclin E/CDK2 complexes, thus facilitating activation of cyclin E/CDK2. Cyclin E/CDK2 complexes phosphorylate p27 leading to its degradation in the nucleus. Human kinase interacting stathmin (hKIS) phosphorylates p27 leading to its nuclear export. Cytoplasmic p27 can inhibit cytochrome $\mathrm{C}$ and procaspases leading to apoptosis. Protein kinase B (PKB)/AKT phosphorylates cytoplasmic p27 inhibiting its nuclear transport. PKB/AKT also phosphorylates the $\mathrm{p} 27$ transcription factor Afx, inhibiting its nuclear entry and thus preventing $p 27$ transcription.

tion [160]. In addition, cyclin D/CDK4/6 complexes sequestrate $\mathrm{p} 27$, serving to titrate p27 away from cyclin E/ CDK2 complexes, which is important for CDK2 activation $[161,162]$. Thus, sequestration as well as the export of p27 from the nucleus to the cytoplasm facilitates activation of cyclin E/CDK2, which maintains low levels of p27 by initiating p27 degradation. There is evidence that p27 is a major target of tyrosine kinase receptors including EGFR and ErbB2/Her2, resulting in cancer cell proliferation by (1) decreasing p27 levels, (2) sequestrating p27 away from cyclin E/CDK2 complexes and (3) causing nucleus-to-cytoplasm transport (nuclear exclusion) of p27 [163-165]. The question arises if cytoplasmic relocalization of p27 is only a means of abrogating its function, or if cytoplasmic p27 has additional effects. For example, it is known that p21 not only inhibits CDK4, but when present in the cytoplasm it can inhibit caspase- 3 by interacting with procaspase-3, thus inhibiting apoptosis [166]. In analogy, cytoplasmic p27 has been shown to prevent 


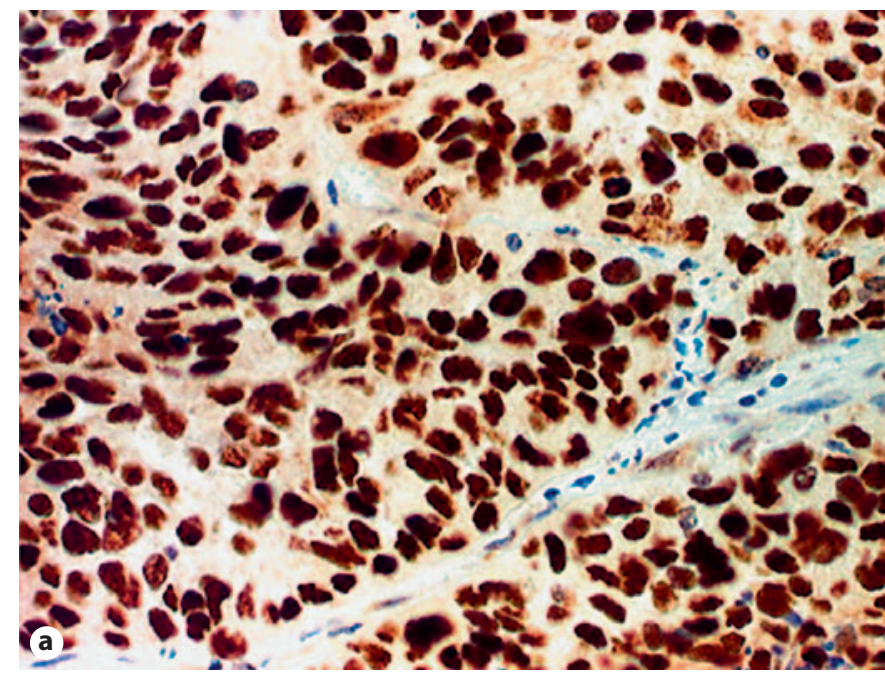

Fig. 5. Immunohistochemical stains for p27. a An SCC with p27 expression only in the nucleus. b An SCC with nuclear and cytoplasmic expression of p27. c A large cell carcinoma with p27 expression only in the cytoplasm. Taking figure 4 into consideration, these different subcellular localizations of p27 are most likely of different, probably biologically completely opposite, functional importance.

cytochrome $\mathrm{C}$ release and also inhibits other procaspases [142]. This indicates that p27 can inhibit apoptosis upstream of mitochondrial function (cytochrome C) as well as downstream where caspases are involved. Supporting the notion of p27 acting as an oncoprotein, studies have linked high p27 expression to higher grades of endometrioid cancer and poorer prognosis [167]. Furthermore, tumors with cytoplasmic expression of p27 are associated with a more aggressive clinical course compared to p27 localized to the nucleus $[168,169]$. Such dual functions of a protein are not a new phenomenon. Another example of a protein that plays at least two distinct roles, depending on nuclear or cytoplasmic localization, is $\beta$-catenin (regulator of transcription and cell adhesion molecule) [37]. Accordingly, one may conclude that the combination of high nuclear and low cytoplasmic expression of
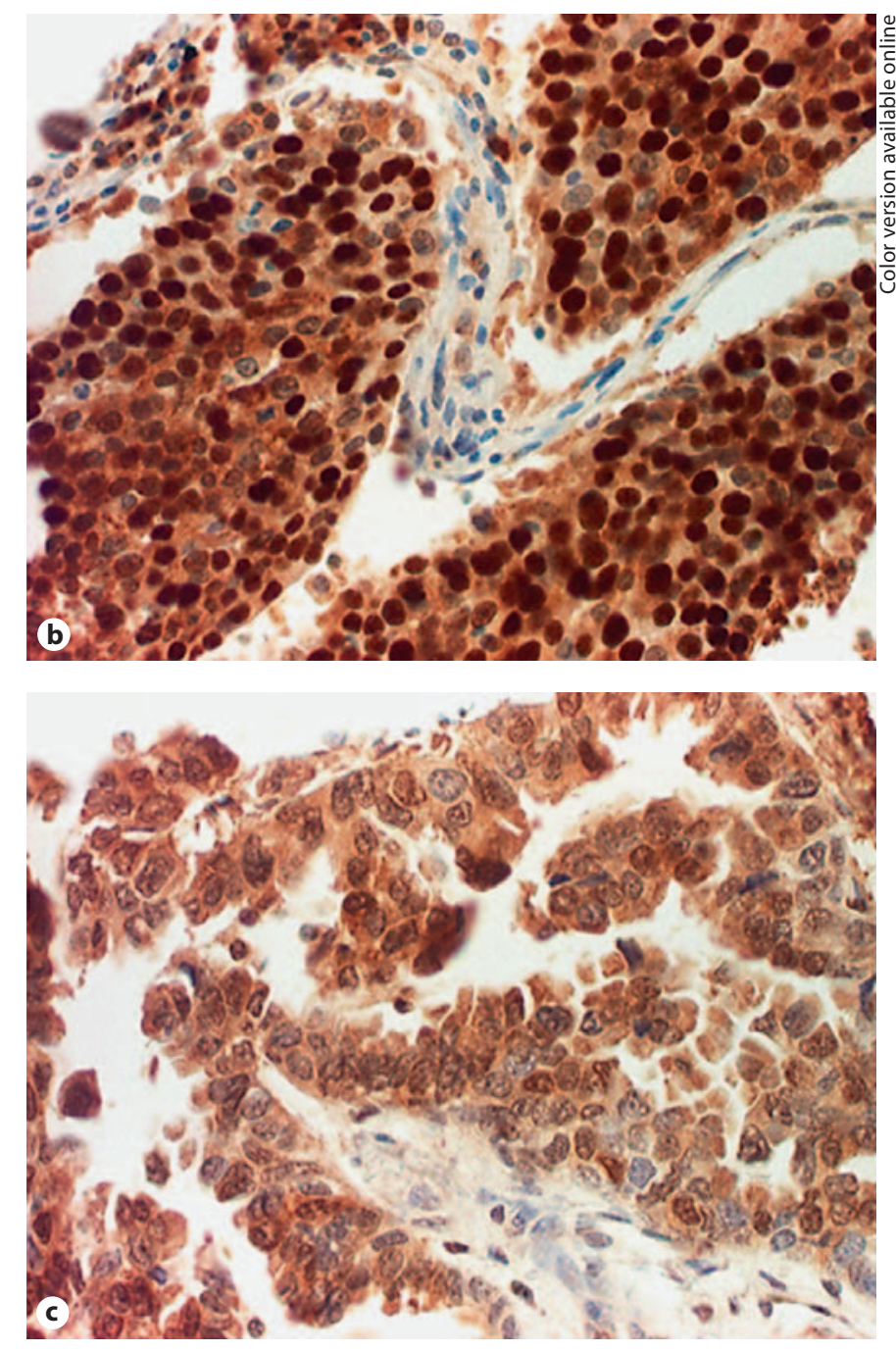

p27 should confer the best prognosis. Indeed, a recent study has reported this correlation for high-grade astrocytomas [169]. Our own observations show that when taking the exact subcellular immunohistochemical staining pattern into account, cytoplasmic and nuclear p27 expression strongly correlate with each other in NSCLC (fig. 5) [37]. In contrast to other reports, overexpression of nuclear p27 was associated with decreased overall survival $[37,48]$. A likely explanation for this controversial finding is the association of p27 with cyclin D, which sequesters p27 in the nucleus, preventing its inhibition of cyclin E/CDK2 complexes. Indeed, our results demonstrated a significant correlation between increased nuclear p27 expression and increased expression of the cyclins D1, D3 and E [37]. In addition, the increased expression of these cyclins was also associated with increased ex- 
pression of p21 [37]. These findings emphasize that immunohistochemical stainings of p27 (and p21) do not necessarily reflect its supposed functions. For additional information, the exact subcellular localization and association with other cell cycle proteins must be taken into account.

\section{p57}

p57 is the least-studied WAF/CIP/KIP member with sparse data in connection with NSCLC. Alterations include frequent loss of heterozygosity with a maternal allele bias, increased methylation of the $p 57$ promoter region leading to decreased expression of $\mathrm{p} 57$ and reduced expression in tumor tissue (compared to normal lung tissue) correlating with increased proliferation [170-172]. Proteolysis via the S-phase-associated kinase protein 2 has been reported as an important mechanism of p57 protein downregulation [170]. It has recently been stated that decreased expression of $\mathrm{p} 57$ in lung cancer is associated with poor postoperative survival time and lymph node spread [173].

\section{Cyclin-Dependent Kinases}

Specific findings regarding deregulation of CDK in NSCLC are sparse. A genomic profiling study comparing 15 early-stage lung ACA with 5 nonneoplastic pulmonary tissue specimens, found (among other cell cyclerelated abnormalities) increased gene expression of CDK2, 4, 7 and 10 [47]. Amplification of the CDK4 gene leading to CDK4 overexpression has been described in lung cancer, and although it is a rare event, this underlines the importance of the RB-cyclin D pathway in lung tumorigenesis [174]. Several molecules designed to inhibit CDK exist and are currently being evaluated in clinical trials [40]. Their efficacy and possible approval for commercial use have yet to be determined. First-generation CDK inhibitors (e.g. flavopiridol) have shown low activity and/or toxicity in clinical trials $[175,176]$. The possibility of other key targets of such agents and failure to reach therapeutic drug concentrations has been discussed $[175,177]$. It has also been suggested that such CDK inhibitors are able to improve the efficacy of other cytotoxic drugs when used in combination [177]. A synergistic benefit has also been described for a secondgeneration CDK inhibitor (aminothiazole SNS-032), which sensitized radioresistant lung cancer cells to ionizing radiation $[175,178]$.

Cell Cycle in Non-Small-Cell Lung

Cancer

\section{Aurora and Polo-Like Kinases}

The Aurora family proteins are highly conserved serine-threonine kinases and are important regulators of mitosis. Aurora A has a crucial role at the G2/M phase of the cell cycle in centrosome maturation and separation during the early prophase. Gene copy number, mRNA levels and protein expression have been found to be increased in many carcinomas, correlating with disease severity [179]. Aurora B, which peaks slightly later than Aurora A, is a member of the chromosomal passenger complex and is involved in histone $\mathrm{H} 3$ phosphorylation, chromosomal condensation, chromosomal alignment on the metaphase plate, bipolar centromere-microtubule attachments, spindle checkpoint and cytokinesis [180]. Aurora $\mathrm{C}$ is thought to have a similar role to Aurora B, but seems to be restricted to the testis [179]. Aurora A and $\mathrm{B}$ are rapidly degraded by the APC proteasomal pathway [181]. Aberrant expression and activity of Aurora kinases disturbs mitotic checkpoints, resulting in genomic instability and aneuploidy and has been implicated in tumorigenesis for various malignancies [182]. Overexpression of Aurora A (transcript and protein) has been reported in NSCLC when compared to nonmalignant lung tissue and was associated with poor tumor differentiation [183]. One study noted that the immunohistochemical staining pattern for Aurora A is of significance, since increased perimembranous staining correlated with higher tumor stage, higher proliferative activity and was an independent predictor of poor prognosis especially for SCC, in contrast to a diffuse cytoplasmic staining pattern [184]. Previous data have shown that by phosphorylating and thus inactivating p53, Aurora A can override cell cycle arrest and apoptosis induced by cisplatin and radiation [185]. The resulting possibility of Aurora A as a predictive marker for NSCLC patients remains to be determined. Upregulation of the Aurora $B$ gene and protein overexpression has also been documented in NSCLC and was correlated with lymph node spread and diminished survival $[186,187]$.

Inhibiting Aurora A leads to cell cycle delay at the G2/M transition followed by abnormal assembly of the microtubule apparatus $[188,189]$. Inhibition of Aurora B results in polyploidy by premature mitotic exit and eventually a higher tendency to undergo apoptosis [190]. Since Aurora B allows the continuation of the cell cycle instead of mitotic arrest, the possibility of combining Aurora $\mathrm{B}$ inhibitors with drugs that act at different phases of the cell cycle is intriguing. Of course, the order of administration would play a crucial role for this assump-

Pathobiology 2012;79:175-194 
tion. Indeed, in a study treating chronic myelogenous leukemia cells first with an Aurora kinase inhibitor followed by idarubicin or cytosine-arbinoside, a greater loss in viability was seen compared to cells that were treated with both agents simultaneously [191]. When both Aurora kinase subtypes are blocked, a phenotype corresponding to the sole inhibition of Aurora B is the result, suggesting that Aurora B deficiency may bypass Aurora A function during mitosis [192]. Currently, a number of Aurora kinase inhibitors are being tested in preclinical and clinical settings as antitumor agents [193]. Studies examining Aurora kinase inhibitors in NSCLC patients have reported disease stabilization as the best response, but various agents are still in the developmental phases and their role for NSCLC has yet to be investigated [193, 194].

Of the four known PLKs (1-4), PLK1 is the best characterized. PLK1 activates cyclin B1/CDK1 complexes and plays a role in centrosome maturation, microtubule dynamics and the separation of sister chromatids during the anaphase $[180,195]$. By activating subunits of the APC, PLK1 is also involved in the exit of cells from mitosis [180, 195]. PLK1 expression is elevated in various types of cancer $[196,197]$. High PLK1 expression has been associated with poor survival in surgically resected NSCLC patients and has been suggested as a marker of high prognostic potential [196]. Therapeutic PLK1 inhibition has recently shown modest efficacy and favorable safety in relapsed stage IIIB and IV NSCLC [198].

\section{Transforming Growth Factor Beta}

Transforming growth factor beta (TGF- $\beta$ ) is one of the most immunosuppressive cytokines produced by tumors and tumor-associated stromal cells, and we have recently shown that its expression correlates with significantly reduced overall survival time in patients with NSCLC [199]. In addition, TGF- $\beta$ plays a crucial role in the cell cycle. SMAD are the predominant transducers of extracellular signals from TGF- $\beta$ to the nucleus where they are activators of transcription. The name SMAD is a fusion of two protein names; SMAD are homologs of both the Drosophila protein 'mothers against decapentaplegic' (MAD) and the Caenorhabditis elegans small (Sma) pathway protein. In normal cells, TGF- $\beta$ signaling causes an antiproliferative response inhibiting the G1/S transition by inducing expression of p15, p21 and p27 and suppressing cyclins A, D1 and $\mathrm{E}$ as well as CDK2 and 4 [62, 200-205]. Furthermore, activation of antimitogenic signaling by TGF- $\beta$ has been reported to suppress cell growth by counteracting delocalization of p27 [157, 165]. TGF- $\beta$ also directly suppresses $C-M Y C$ expression [206]. The product of the $R B$ gene has also been implicated as a target of TGF- $\beta$-induced signaling, and the activity of RB and other RBassociated molecules is required for TGF- $\beta$ to efficiently suppress cell growth $[206,207]$. During malignant transformation of a cell, several components of the TGF- $\beta$ signaling pathway become altered, resulting in TGF- $\beta$ resistance of tumor cells, which is a frequent occurrence in NSCLC [208]. TGF- $\beta$-resistant cancer cells proliferate uncontrollably, and can further increase the amount of TGF- $\beta$. In this setting, TGF- $\beta$ causes invasiveness of tumor cells, immunosuppression and angiogenesis by influencing various other cells, e.g. surrounding stromal cells, immune cells, endothelial and smooth-muscle cells [209]. Resistance to TGF- $\beta$-mediated growth inhibition is often a result of mutation or loss of expression of the genes involved in the TGF- $\beta$ signaling pathway. Somatic mutations are rather infrequent but can occur in TGF- $\beta$ receptors and SMAD in NSCLC $[209,210]$. Loss of TGF- $\beta$ receptor expression has been observed more commonly and was associated with aberrant promoter methylation [211]. An in vitro study showed that overexpression of the TGF- $\beta$ receptor II restored TGF- $\beta$ sensitivity and reduced tumor growth in lung cancer cells [212]. Data on targeting the TGF- $\beta$ signaling pathways in lung cancer are sparse; however, a recent study suggests that deactivating the inhibitory downstream molecule SMAD6 may improve patient outcome [213]. Taken together, TGF- $\beta$ plays a complex and often diverse role in cancer which requires further clarification, particularly with regard to possible therapeutic approaches involving TGF- $\beta$ pathways.

\section{Ki-67}

$\mathrm{Ki}-67$ is a general and often analyzed cell cycle-related marker. It is a DNA-binding nuclear protein that is expressed throughout the cell cycle only in proliferating cells and is therefore often used as a marker to evaluate proliferation of tumors [133]. Although Ki-67 is one of the most-studied parameters, data concerning its prognostic value in NSCLC are inconsistent [48]. In a meta-analysis, $\mathrm{Ki}-67$ overexpression was found to be a poor prognostic factor for survival in patients with NSCLC [214]. Ki-67 is used routinely for assisting the grading of tumors of the central nervous system, which may also be a possibility for NSCLC, since it has been shown that an increasing 
Table 1. Reported characteristics of regulators of the cell cycle in NSCLC

\begin{tabular}{|c|c|c|c|c|}
\hline Parameter & Frequently reported abnormalities & $\begin{array}{l}\text { Prognostic } \\
\text { association }\end{array}$ & Predictive association & Targeted therapy \\
\hline Cyclin A & overexpression & & & \\
\hline Cyclin B1 & overexpression & poor prognosis & & \\
\hline Cyclin D & amplification, overexpression & poor prognosis & $\begin{array}{l}\text { reduced expression may pre- } \\
\text { dict sensitivity to TKI [72] }\end{array}$ & \\
\hline $\mathrm{CDK}$ & gene amplification, overexpression & & & $\begin{array}{l}\text { flavopiridol [218], } \\
\text { R-roscovitine [219, 220], } \\
\text { AZ703 [221] }\end{array}$ \\
\hline p16 & $\begin{array}{l}\text { promoter hypermethylation, gene deletion, } \\
\text { loss of expression }\end{array}$ & poor prognosis & & azacitidine [102] \\
\hline p53 & mutation, (overexpression) & $\begin{array}{l}\text { poor prognosis } \\
\text { (weak) }\end{array}$ & cisplatin sensitivity & \\
\hline p57 & $\begin{array}{l}\text { promoter hypermethylation, } \\
\text { loss of heterozygosity, reduced expression }\end{array}$ & poor prognosis & & \\
\hline Aurora A & overexpression & poor prognosis & $\begin{array}{l}\text { cisplatin and radiotherapy } \\
\text { sensitivity }\end{array}$ & $\begin{array}{l}\text { benzopyridoindoles [222] } \\
\text { VX-680 [223] } \\
\text { AT9283 [224] } \\
\text { MLN8237 [225] } \\
\text { PF03814735[226] }\end{array}$ \\
\hline Aurora B & gene amplification, overexpression & poor prognosis & & $\begin{array}{l}\text { AZD1152 [227] } \\
\text { GSK1070916 [228] }\end{array}$ \\
\hline
\end{tabular}

Ki-67 value correlates with higher (less differentiated) tumor grades [215, 216], but in contrast to growth patterns of ACA $[14,217]$, this has not (yet) been shown to be of prognostic significance.

\section{Concluding Remarks}

Over the past decades NSCLC has remained the number one cause for cancer-related deaths worldwide. Early disease detection is infrequent due to the late onset of symptoms and many cases comprise primarily palliative care. The TNM classification scheme is still the most reliable means for overall prognosis, but its value for each individual is debatable. Improved markers to prognosticate survival and predict response to therapy are needed. Many reports provide evidence for the importance of regulators of the cell cycle in NSCLC. Most NSCLC have de- tectable cell cycle abnormalities, and multiple defects are commonly seen in a single tumor. The more defective the cell cycle becomes, the more severe seem to be the consequences. Prognostic power has been attributed to various cell cycle markers, especially those involved in the cyclin $\mathrm{D}$-CDK4/6-RB pathway, which play a major role at the G1/S transition. An important issue is determining which genetic alterations are driver and which are rather passenger events. A clue may be provided by their frequency and time of occurrence. For example, genetic alterations of p16 and CCND1 are frequently found and have been described at an early stage of tumorigenesis as well as in precursor lesions, indicating their significance. CKI seem to be associated with the response to certain anticancer drugs, since the loss of CKI may sensitize tumor cells to antiproliferative agents and thus improve efficacy. An important point when analyzing cell cycle-related parameters, which is frequently performed by immunohis- 
tochemical examination of protein expression, is the exact subcellular localization. Different localizations (e.g. nuclear vs. cytoplasmic) often confer converse effects and must be adequately assessed. In addition, analyzing a single marker is likely insufficient, since interactions between cell cycle regulators affect each other and should be evaluated simultaneously. The fact that cell cycle markers are not yet part of the routine workup of NSCLC is most likely due to the prognostic strength of standard parameters (e.g. the TNM classification), the variability of technical methods of assessment of such markers and the rather poor reproducibility of their interpretation as well as the complex and vast interactions of these cell cycle-related factors. The cell cycle as a therapeutic target is also gaining significance and different promising approaches are currently under investigation, including inhibitors of CDK and Aurora kinases. In conclusion, the cell cycle offers a multitude of prognostic, predictive and therapeutic possibilities, many of which are still in the developmental phase. Progress in this field is ongoing and has the potential to improve the current scenario for NSCLC patients (table 1).

\section{References}

1 Jemal A, Bray F, Center MM, Ferlay J, Ward E, Forman D: Global cancer statistics. CA Cancer J Clin 2011;61:69-90.

$\checkmark 2$ Alberg AJ, Samet JM: Epidemiology of lung cancer. Chest 2003;123:21S-49S.

-3 Thun MJ, Henley SJ, Calle EE: Tobacco use and cancer: an epidemiologic perspective for geneticists. Oncogene 2002;21:7307-7325.

4 Haussmann HJ: Smoking and lung cancer: future research directions. Int J Toxicol 2007; 26:353-364.

5 Sasco AJ, Secretan MB, Straif K: Tobacco smoking and cancer: a brief review of recent epidemiological evidence. Lung Cancer 2004;2:S3-S9.

-6 Bray FI, Weiderpass E: Lung cancer mortality trends in 36 European countries: secular trends and birth cohort patterns by sex and region 1970-2007. Int J Cancer 2010;126 1454-1466.

7 Youlden DR, Cramb SM, Baade PD: The international epidemiology of lung cancer: geographical distribution and secular trends. J Thorac Oncol 2008;3:819-831.

8 Spitz M, Wu X, Wilkinson A, Wei Q (eds): Cancer of the Lung. Oxford, Oxford University Press, 2006.

9 Travis W, Brambilla E, Müller-Hermelink H, Harris C (eds): Pathology and Genetics of Tumours of the Lung, Pleura, Thymus and Heart. Lyon, IARC Press, 2004.

10 Sakurai H, Asamura H, Watanabe S, Suzuki $\mathrm{K}$, Tsuchiya R: Clinicopathologic features of peripheral squamous cell carcinoma of the lung. Ann Thorac Surg 2004;78:222-227.

-11 Beadsmoore CJ, Screaton NJ: Classification, staging and prognosis of lung cancer. Eur J Radiol 2003;45:8-17.

-12 Subramanian J, Govindan R: Lung cancer in never smokers: a review. J Clin Oncol 2007; 25:561-570.

13 Yang P, Cerhan JR, Vierkant RA, Olson JE, Vachon CM, Limburg PJ, Parker AS, Anderson $\mathrm{KE}$, Sellers TA: Adenocarcinoma of the lung is strongly associated with cigarette smoking: further evidence from a prospective study of women. Am J Epidemiol 2002;156:1114-1122.
14 Travis WD, Brambilla E, Noguchi M, Nicholson AG, Geisinger KR, Yatabe Y, Beer DG, Powell CA, Riely GJ, Van Schil PE, Garg K, Austin JH, Asamura H, Rusch VW, Hirsch FR, Scagliotti G, Mitsudomi T, Huber RM, Ishikawa Y, Jett J, Sanchez-Cespedes M, Sculier JP, Takahashi T, Tsuboi M, Vansteenkiste J, Wistuba I, Yang PC, Aberle D, Brambilla C, Flieder D, Franklin W, Gazdar A, Gould $\mathrm{M}$, Hasleton $\mathrm{P}$, Henderson D, Johnson B, Johnson D, Kerr K, Kuriyama K, Lee JS, Miller VA, Petersen I, Roggli V, Rosell R, Saijo N, Thunnissen E, Tsao M, Yankelewitz D: International Association for the Study of Lung Cancer/American Thoracic Society/European Respiratory Society international multidisciplinary classification of lung adenocarcinoma. J Thorac Oncol 2011;6:244-285.

15 Jackman DM, Johnson BE: Small-cell lung cancer. Lancet 2005;366:1385-1396.

16 Birring SS, Peake MD: Symptoms and the early diagnosis of lung cancer. Thorax 2005; 60:268-269.

17 Sherwood JT, Brock MV: Lung cancer: new surgical approaches. Respirology 2007;12: 326-332.

18 Colice GL, Shafazand S, Griffin JP, Keenan $\mathrm{R}$, Bolliger CT, American College of Chest Physicians: Physiologic evaluation of the patient with lung cancer being considered for resectional surgery: ACCP evidenced-based clinical practice guidelines, ed 2. Chest 2007; 132:161S-177S

19 Salomaa ER, Sällinen S, Hiekkanen H, Liippo K: Delays in the diagnosis and treatment of lung cancer. Chest 2005;128:2282-2288.

20 Arriagada R, Bergman B, Dunant A, Le Chevalier T, Pignon JP, Vansteenkiste J, International Adjuvant Lung Cancer Trial Collaborative Group: Cisplatin-based adjuvant chemotherapy in patients with completely resected non-small-cell lungcancer. N Engl J Med 2004;350:351-360.

21 Douillard JY, Rosell R, De Lena M, Carpagnano F, Ramlau R, Gonzáles-Larriba JL, Grodzki T, Pereira JR, Le Groumellec A, Lorusso V, Clary C, Torres AJ, Dahabreh J, Sou- quet PJ, Astudillo J, Fournel P, Artal-Cortes A Jassem J, Koubkova L, His P, Riggi M, Hurteloup P: Adjuvant vinorelbine plus cisplatin versus observation in patients with completely resected stage IB-IIIA non-small-cell lung cancer (Adjuvant Navelbine International Trialist Association [ANITA]): a randomised controlled trial. Lancet Oncol 2006;7:719-727.

22 Winton T, Livingston R, Johnson D, Rigas J, Johnston M, Butts C, Cormier Y, Goss G, Inculet R, Vallieres E, Fry W, Bethune D, Ayoub J, Ding K, Seymour L, Graham B, Tsao MS, Gandara D, Kesler K, Demmy T, Shepherd F, National Cancer Institute of Canada Clinical Trials Group, National Cancer Institute of the US Intergroup JBR.10 Trial Investigators: Vinorelbine plus Cisplatin versus observation in resected non-small-cell lung cancer. $\mathrm{N}$ Engl J Med 2005;352:2589-2597.

-23 Strauss GM, Herndon JE 2nd, Maddaus MA, Johnstone DW, Johnson EA, Harpole DH, Gillenwater HH, Watson DM, Sugarbaker DJ, Schilsky RL, Vokes EE, Green MR: Adjuvant paclitaxel plus carboplatin compared with observation in stage IB non-small-cell lung cancer: CALGB 9633 with the Cancer and Leukemia Group B, Radiation Therapy Oncology Group and North Central Cancer Treatment Group Study Groups. J Clin Oncol 2008;26:5043-5051.

24 Forrest LM, McMillan DC, McArdle CS, Angerson WJ, Dagg K, Scott HR: A prospective longitudinal study of performance status, an inflammation-based score (GPS) and survival in patients with inoperable non-small-cell lung cancer. Br J Cancer 2005;92:1834-1836.

25 Rosell R, Moran T, Queralt C, Porta R, Cardenal F, Camps C, Majem M, Lopez-Vivanco $G$, Isla $D$, Provencio $M$, Insa $A$, Massuti B, Gonzalez-Larriba JL, Paz-Ares L, Bover I, Garcia-Campelo R, Moreno MA, Catot S, Rolfo C, Reguart N, Palmero R, Sánchez JM, Bastus R, Mayo C, Bertran-Alamillo J, Molina MA, Sanchez JJ, Taron M: Spanish Lung Cancer Group. Screening for epidermal growth factor receptor mutations in lung cancer. N Engl J Med 2009;361:958-967. 
-26 Kwak EL, Bang YJ, Camidge DR, Shaw AT, Solomon B, Maki RG, Ou SH, Dezube BJ, Jänne PA, Costa DB, Varella-Garcia M, Kim WH, Lynch TJ, Fidias P, Stubbs H, Engelman JA, Sequist LV, Tan W, Gandhi L, Mino-Kenudson M, Wei GC, Shreeve SM, Ratain MJ, Settleman J, Christensen JG, Haber DA, Wilner K, Salgia R, Shapiro GI, Clark JW, Iafrate AJ: Anaplastic lymphoma kinase inhibition in non-small-cell lung cancer. N Engl J Med 2010;363:1693-1703.

27 Dimou A, Harrington K, Syrigos KN: From the bench to bedside: biological and methodology considerations for the future of companion diagnostics in nonsmall cell lung cancer. Patholog Res Int 2011;2011:312-346.

28 Brundage MD, Davies D, Mackillop WJ: Prognostic factors in non-small cell lung cancer: a decade of progress. Chest 2002;122: 1037-1057.

29 Endoh H, Tomida S, Yatabe Y, Konishi H, Osada H, Tajima K, Kuwano H, Takahashi T, Mitsudomi T: Prognostic model of pulmonary adenocarcinoma by expression profiling of eight genes as determined by quantitative real-time reverse transcriptase polymerase chain reaction. J Clin Oncol 2004;22: 811-819.

- 30 Wigle DA, Jurisica I, Radulovich N, Pintilie M, Rossant J, Liu N, Lu C, Woodgett J, Seiden I, Johnston M, Keshavjee S, Darling G, Winton T, Breitkreutz BJ, Jorgenson P, Tyers M, Shepherd FA, Tsao MS: Molecular profiling of non-small cell lung cancer and correlation with disease-free survival. Cancer Res 2002; 62:3005-3008.

- 31 Beer DG, Kardia SL, Huang CC, Giordano TJ, Levin AM, Misek DE, Lin L, Chen G, Gharib TG, Thomas DG, Lizyness ML, Kuick R, Hayasaka S, Taylor JM, Iannettoni MD, Orringer MB, Hanash S: Gene-expression profiles predict survival of patients with lung adenocarcinoma. Nat Med 2002;8:816824.

- 32 Schneider PM, Praeuer HW, Stoeltzing O, Boehm J, Manning J, Metzger R, Fink U, Wegerer S, Hoelscher AH, Roth JA: Multiple molecular marker testing (p53, C-Ki-ras, cerbB-2) improves estimation of prognosis in potentially curative resected non-small cell lung cancer. Br J Cancer 2000;83:473-479.

-33 Malumbres M, Barbacid M: Cell cycle, CDKs and cancer: a changing paradigm. Nat Rev Cancer 2009;9:153-166.

- 34 Catzavelos C, Bhattacharya N, Ung YC, Wilson JA, Roncari L, Sandhu C, Shaw P, Yeger H, Morava-Protzner I, Kapusta L, Franssen E, Pritchard KI, Slingerland JM: Decreased levels of the cell-cycle inhibitor p27Kip1 protein: prognostic implications in primary breast cancer. Nat Med 1997;3:227-230.

- 35 Esposito V, Baldi A, De Luca A, Groger AM, Loda M, Giordano GG, Caputi M, Baldi F, Pagano M, Giordano A: Prognostic role of the cyclin-dependent kinase inhibitor p27 in non-small cell lung cancer. Cancer Res 1997; 57:3381-3385.
36 Sterlacci W, Tzankov A, Veits L, Zelger B, Bihl MP, Foerster A, Augustin F, Fiegl M, Savic S: A comprehensive analysis of p16 expression, gene status, and promoter hypermethylation in surgically resected non-small cell lung carcinomas. J Thorac Oncol 2011;6: 1649-1657.

37 Sterlacci W, Fiegl M, Hilbe W, Jamnig H, Oberaigner W, Schmid T, Augustin F, Auberger J, Obermann EC, Tzankov A: Deregulation of p27 and cyclin D1/D3 control over mitosis is associated with unfavorable prognosis in non-small cell lung cancer, as determined in 405 operated patients. J Thorac Oncol 2010;5:1325-1336.

38 Giacinti C, Giordano A: RB and cell cycle progression. Oncogene 2006;25:5220-5227.

39 van den Heuvel S, Harlow E: Distinct roles for cyclin-dependent kinases in cell cycle control. Science 1993;262:2050-2054.

40 Eymin B, Gazzeri S: Role of cell cycle regulators in lung carcinogenesis. Cell Adh Migr 2010;4:114-123.

41 Malumbres M, Barbacid M: Mammalian cyclin-dependent kinases. Trends Biochem Sci 2005;30:630-641.

42 Peters JM: The anaphase promoting complex/cyclosome: a machine designed to destroy. Nat Rev Mol Cell Biol 2006;7:644-656.

43 Sherr CJ, Roberts JM: CDK inhibitors: positive and negative regulators of G1-phase progression. Genes Dev 1999;13:1501-1512.

44 Hanahan D, Weinberg RA: The hallmarks of cancer. Cell 2000;100:57-70.

-45 Malumbres M, Barbacid M: To cycle or not to cycle: a critical decision in cancer. Nat Rev Cancer 2001;1:222-231.

46 Massagué J: G1 cell-cycle control and cancer. Nature 2004;432:298-306.

47 Singhal S, Amin KM, Kruklitis R, DeLong P, Friscia ME, Litzky LA, Putt ME, Kaiser LR, Albelda SM: Alterations in cell cycle genes in early stage lung adenocarcinoma identified by expression profiling. Cancer Biol Ther 2003;2:291-298.

48 Zhu CQ, Shih W, Ling CH, Tsao MS: Immunohistochemical markers of prognosis in non-small cell lung cancer: a review and proposal for a multiphase approach to marker evaluation. J Clin Pathol 2006;59:790-800.

49 Quelle DE, Ashmun RA, Shurtleff SA, Kato JY, Bar-Sagi D, Roussel MF, Sherr CJ: Overexpression of mouse D-type cyclins accelerates G1 phase in rodent fibroblasts. Genes Dev 1993;7:1559-1571.

50 Imoto M, Doki Y, Jiang W, Han EK, Weinstein IB: Effects of cyclin D1 overexpression on G1 progression-related events. Exp Cell Res 1997;236:173-180.

51 Resnitzky D, Gossen M, Bujard H, Reed SI: Acceleration of the G1/S phase transition by expression of cyclins D1 and E with an inducible system. Mol Cell Biol 1994;14:1669-1679.
2 Marchetti A, Doglioni C, Barbareschi M, Buttitta F, Pellegrini S, Gaeta P, La Rocca R, Merlo G, Chella A, Angeletti CA, Dalla Palma P, Bevilacqua G: Cyclin D1 and retinoblastoma susceptibility gene alterations in non-small cell lung cancer. Int J Cancer 1998; 75:187-192.

53 Betticher DC, Heighway J, Hasleton PS, Altermatt HJ, Ryder WD, Cerny T, Thatcher N: Prognostic significance of CCND1 (cyclin D1) overexpression in primary resected nonsmall-cell lung cancer. Br J Cancer 1996;73: 294-300.

54 Jiang W, Kahn SM, Tomita N, Zhang YJ, Lu SH, Weinstein IB: Amplification and expression of the human cyclin $\mathrm{D}$ gene in esophageal cancer. Cancer Res 1992;52:2980-2983.

55 Gillett C, Fantl V, Smith R, Fisher C, Bartek J, Dickson C, Barnes D, Peters G: Amplification and overexpression of cyclin D1 in breast cancer detected by immunohistochemical staining. Cancer Res 1994;54: 1812-1817.

56 Gautschi O, Ratschiller D, Gugger M, Betticher DC, Heighway J: Cyclin D1 in nonsmall cell lung cancer: a key driver of malignant transformation. Lung Cancer 2007;55: $1-14$.

57 Yoo J, Jung JH, Lee MA, Seo KJ, Shim BY, Kim SH, Cho DG, Ahn MI, Kim CH, Cho KD, Kang SJ, Kim HK: Immunohistochemical analysis of non-small cell lung cancer: correlation with clinical parameters and prognosis. J Korean Med Sci 2007;22:318325 .

58 Burke L, Flieder DB, Guinee DG, Brambilla E, Freedman AN, Bennett WP, Jones RT, Borkowski A, Caporaso NA, Fleming M, Trastek V, Pairolero P, Tazelaar H, Midthun D, Jett JR, Liotta LA, Travis WD, Harris CC: Prognostic implications of molecular and immunohistochemical profiles of the $\mathrm{Rb}$ and p53 cell cycle regulatory pathways in primary non-small cell lung carcinoma. Clin Cancer Res 2005;11:232-241.

59 Myong NH: Cyclin D1 overexpression, p16 loss, and $\mathrm{pRb}$ inactivation play a key role in pulmonary carcinogenesis and have a prognostic implication for the long-term survival in non-small cell lung carcinoma patients. Cancer Res Treat 2008;40:45-52.

60 Betticher DC, Thatcher N, Altermatt HJ, Hoban P, Ryder WD, Heighway J: Alternate splicing produces a novel cyclin D1 transcript. Oncogene 1995;11:1005-1011.

61 Esposito V, Baldi A, De Luca A, Tonini G, Vincenzi B, Santini D, Persichetti P, Mancini A, Citro G, Baldi F, Groeger AM, Caputi M: Cell cycle related proteins as prognostic parameters in radically resected non-small cell lung cancer. J Clin Pathol 2005;58:734-739.

62 Knudsen KE, Diehl JA, Haiman CA, Knudsen ES: Cyclin D1: polymorphism, aberrant splicing and cancer risk. Oncogene 2006;25: 1620-1628. 
63 Li R, An SJ, Chen ZH, Zhang GC, Zhu JQ, Nie Q, Xie Z, Guo AL, Mok TS, Wu YL: Expression of cyclin D1 splice variants is differentially associated with outcome in nonsmall cell lung cancer patients. Hum Pathol 2008;39:1792-1801.

64 Lonardo F, Rusch V, Langenfeld J, Dmitrovsky E, Klimstra DS: Overexpression of cyclins $\mathrm{D} 1$ and $\mathrm{E}$ is frequent in bronchial preneoplasia and precedes squamous cell carcinoma development. Cancer Res 1999;59: 2470-2476.

65 Cooper WA, Kohonen-Corish MR, McCaughan B, Kennedy C, Sutherland RL, Lee CS: Expression and prognostic significance of cyclin B1 and cyclin A in non-small cell lung cancer. Histopathology 2009;55:28-36.

- 66 Yoshida T, Tanaka S, Mogi A, Shitara Y, Kuwano $\mathrm{H}$ : The clinical significance of cyclin B1 and Weel expression in non-small-cell lung cancer. Ann Oncol 2004;15:252-256.

-67 Soria JC, Jang SJ, Khuri FR, Hassan K, Liu D, Hong WK, Mao L: Overexpression of cyclin $\mathrm{B} 1$ in early-stage non-small cell lung cancer and its clinical implication. Cancer Res 2000;60:4000-4004.

- 68 Volm M, Rittgen W, Drings P: Prognostic value of ERBB-1, VEGF, cyclin A, FOS, JUN and MYC in patients with squamous cell lung carcinomas. Br J Cancer 1998;77:663-669.

-69 Müller-Tidow C, Metzger R, Kügler K, Diederichs S, Idos G, Thomas M, DockhornDworniczak B, Schneider PM, Koeffler HP, Berdel WE, Serve H: Cyclin E is the only cyclin-dependent kinase 2-associated cyclin that predicts metastasis and survival in early stage non-small cell lung cancer. Cancer Res 2001;61:647-653.

-70 Volm M, Koomägi R, Mattern J, Stammler G: Cyclin A is associated with an unfavourable outcome in patients with non-small-cell lung carcinomas. Br J Cancer 1997;75:17741778 .

-71 Dobashi Y, Jiang SX, Shoji M, Morinaga S, Kameya T: Diversity in expression and prognostic significance of G1/S cyclins in human primary lung carcinomas. J Pathol 2003;199: 208-220.

72 Kobayashi S, Shimamura T, Monti S, Steidl U, Hetherington CJ, Lowell AM, Golub T, Meyerson M, Tenen DG, Shapiro GI, Halmos B: Transcriptional profiling identifies cyclin D1 as a critical downstream effector of mutant epidermal growth factor receptor signaling. Cancer Res 2006;66:11389-11398.

-73 Sordella R, Bell DW, Haber DA, Settleman J: Gefitinib-sensitizing EGFR mutations in lung cancer activate anti-apoptotic pathways. Science 2004;305:1163-1167.

-74 Amann J, Kalyankrishna S, Massion PP, Ohm JE, Girard L, Shigematsu H, Peyton M, Juroske D, Huang Y, Stuart Salmon J, Kim YH, Pollack JR, Yanagisawa K, Gazdar A, Minna JD, Kurie JM, Carbone DP: Aberrant epidermal growth factor receptor signaling and enhanced sensitivity to EGFR inhibitors in lung cancer. Cancer Res 2005;65:226-235.
Turkson J: STAT proteins as novel targets for cancer drug discovery. Expert Opin Ther Targets 2004;8:409-422.

76 Stacey DW: Cyclin D1 serves as a cell cycle regulatory switch in actively proliferating cells. Curr Opin Cell Biol 2003;15:158-163.

77 Naoki K, Chen TH, Richards WG, Sugarbaker DJ, Meyerson M: Missense mutations of the BRAF gene in human lung adenocarcinoma. Cancer Res 2002;62:7001-7003.

78 Shapiro GI: Preclinical and clinical development of the cyclin-dependent kinase inhibitor flavopiridol. Clin Cancer Res 2004; 10: 4270s-4275s.

79 Grabsch H, Lickvers K, Hansen O, Takeno S, Willers R, Stock W, Gabbert HE, Mueller W: Prognostic value of cyclin B1 protein expression in colorectal cancer. Am J Clin Pathol 2004;122:511-516.

-80 Nozoe T, Korenaga D, Kabashima A, Ohga T, Saeki H, Sugimachi K: Significance of cyclin $\mathrm{B} 1$ expression as an independent prognostic indicator of patients with squamous cell carcinoma of the esophagus. Clin Cancer Res 2002;8:817-822.

81 Toyoshima F, Moriguchi T, Wada A, Fukuda M, Nishida E: Nuclear export of cyclin B1 and its possible role in the DNA damage-induced G2 checkpoint. EMBO J 1998;17: 2728-2735.

82 Harbour JW, Lai SL, Whang-Peng J, Gazdar AF, Minna JD, Kaye FJ: Abnormalities in structure and expression of the human retinoblastoma gene in SCLC. Science 1988;241: 353-357.

83 Haga Y, Hiroshima K, Iyoda A, Shibuya K, Shimamura F, Iizasa T, Fujisawa T, Ohwada $\mathrm{H}$ : Ki-67 expression and prognosis for smokers with resected stage I non-small cell lung cancer. Ann Thorac Surg 2003;75:1727-1732.

84 Reissmann PT, Koga H, Takahashi R, Figlin RA, Holmes EC, Piantadosi S, Cordon-Cardo C, Slamon DJ: Inactivation of the retinoblastoma susceptibility gene in non-smallcell lung cancer. The Lung Cancer Study Group. Oncogene 1993;8:1913-1919.

- 85 D’Amico TA, Massey M, Herndon JE 2nd, Moore MB, Harpole DH Jr: A biologic risk model for stage I lung cancer: immunohistochemical analysis of 408 patients with the use of ten molecular markers. J Thorac Cardiovasc Surg 1999;117:736-743.

86 Singhal S, Vachani A, Antin-Ozerkis D, Kaiser LR, Albelda SM: Prognostic implications of cell cycle, apoptosis, and angiogenesis biomarkers in non-small cell lung cancer: a review. Clin Cancer Res 2005;11:3974-3986.

87 Esposito V, Baldi A, Tonini G, Vincenzi B, Santini M, Ambrogi V, Mineo TC, Persichetti P, Liuzzi G, Montesarchio V, Wolner E, Baldi F, Groeger AM: Analysis of cell cycle regulator proteins in non-small cell lung cancer. J Clin Pathol 2004;57:58-63.
88 Cheng YL, Lee SC, Harn HJ, Chen CJ, Chang YC, Chen JC, Yu CP: Prognostic prediction of the immunohistochemical expression of p53 and p16 in resected non-small cell lung cancer. Eur J Cardiothorac Surg 2003;23: 221-228.

89 Panani AD, Maliaga K, Babanaraki A, Bellenis I: Numerical abnormalities of chromosome 9 and p16CDKN2A gene deletion detected by FISH in non-small cell lung cancer. Anticancer Res 2009;29:4483-4487.

90 Cairns P, Polascik TJ, Eby Y, Tokino K, Califano J, Merlo A, Mao L, Herath J, Jenkins R, Westra W, Rutter JL, Buckler A, Gabrielson E, Tockman M, Cho KR, Hedrick L, Bova GS, Isaacs W, Koch W, Schwab D, Sidransky D: Frequency of homozygous deletion at p16/ CDKN2 in primary human tumours. Nat Genet 1995;11:210-212.

91 GazzeriS, Gouyer V, Vour'ch C, Brambilla C, Brambilla E: Mechanisms of p16INK4A inactivation in non-small-cell lung cancers. Oncogene 1998; 16:497-504.

92 Taga S, Osaki T, Ohgami A, Imoto H, Yoshimatsu T, Yoshino I, Yano K, Nakanishi R, Ichiyoshi Y, Yasumoto K: Prognostic value of the immunohistochemical detection of p16INK4 expression in nonsmall cell lung carcinoma. Cancer 1997;80:389-395.

93 Jin M, Inoue S, Umemura T, Moriya J, Arakawa M, Nagashima K, Kato H: Cyclin D1, p16 and retinoblastoma gene product expression as a predictor for prognosis in nonsmall cell lung cancer at stages I and II. Lung Cancer 2001;34:207-218.

94 Paulsen M, Ferguson-Smith AC: DNA methylation in genomic imprinting, development, and disease. J Pathol 2001;195:97-110.

95 Gray SG, Eriksson T, Ekström TJ: Methylation, gene expression and the chromatin connection in cancer (review). Int J Mol Med 1999;4:333-350.

96 Hong YS, Roh MS, Kim NY, Lee HJ, Kim HK, Lee KE, Kwak JY, Kim JY: Hypermethylation of p16INK4a in Korean non-small cell lung cancer patients. J Korean Med Sci 2007; 22:S32-S37.

97 Guzman LM, Koriyama C, Akiba S, Eizuru Y, Castillo D, Corvalan A, Aguayo FR: High frequency of p16 promoter methylation in non-small cell lung carcinomas from Chile. Biol Res 2007;40:365-372.

98 Hilbe W, Dirnhofer S, Greil R, Wöll E: Biomarkers in non-small cell lung cancer prevention. Eur J Cancer Prev 2004;13:425-436.

99 Belinsky SA, Liechty KC, Gentry FD, Wolf HJ, Rogers J, Vu K, Haney J, Kennedy TC, Hirsch FR, Miller Y, Franklin WA, Herman JG, Baylin SB, Bunn PA, Byers T: Promoter hypermethylation of multiple genes in sputum precedes lung cancer incidence in a high-risk cohort. Cancer Res 2006;66:33383344. 
-100 Kurkjian C, Kummar S, Murgo AJ: DNA -112 Kwon MS, Lee YI, Lee KY: p21 as a prognosmethylation: its role in cancer development and therapy. Curr Probl Cancer 2008;32: 187-235.

101 Vigil CE, Martin-Santos T, Garcia-Manero G: Safety and efficacy of azacitidine in myelodysplastic syndromes. Drug Des Devel Ther 2010;4:221-229.

-102 Juergens RA, Vendetti F, Coleman B, Sebree RS, Rudeck MA, Belinsky S, Brock M, Herman J, Baylin S, Rudin CM: Interim analysis of a phase II trial of 5-azacitidine (5AC) and entinostat (SNDX-275) in relapsed advanced lung cancer (NSCLC). J Clin Oncol 2009;27:15s (abstract 8055).

103 Packenham JP, Taylor JA, White CM, Anna $\mathrm{CH}$, Barrett JC, Devereux TR: Homozygous deletions at chromosome 9p21 and mutation analysis of p16 and p15 in microdissected primary non-small cell lung cancers. Clin Cancer Res 1995;1:687-690.

104 Xiao S, Li D, Corson JM, Vijg J, Fletcher JA: Codeletion of p15 and p16 genes in primary non-small cell lung carcinoma. Cancer Res 1995;55:2968-2971.

-105 Hamada K, Kohno T, Kawanishi M, Ohwada S, Yokota J: Association of CDKN2A(p16)/CDKN2B(p15) alterations and homozygous chromosome arm $9 \mathrm{p}$ deletions in human lung carcinoma. Genes Chromosomes Cancer 1998;22:232-240.

-106 Herman JG, Jen J, Merlo A, Baylin SB: Hypermethylation-associated inactivation indicates a tumor suppressor role for p15INK4B. Cancer Res 1996;56:722-727.

-107 Furonaka O, Takeshima Y, Awaya H, Ishida $\mathrm{H}$, Kohno N, Inai K: Aberrant methylation of p14(ARF), p15(INK4b) and p16(INK4a) genes and location of the primary site in pulmonary squamous cell carcinoma. Pathol Int 2004;54:549-555.

108 Kawamata N, Miller CW, Koeffler HP: Molecular analysis of a family of cyclin-dependent kinase inhibitor genes (p15/MTS2/ INK4b and p18/INK4c) in non-small cell lung cancers. Mol Carcinog 1995;14:263268.

109 Ma H, Chen J, Pan S, Dai J, Jin G, Hu Z, Shen $\mathrm{H}$, Shu Y: Potentially functional polymorphisms in cell cycle genes and the survival of non-small cell lung cancer in a Chinese population. Lung Cancer 2011;73:32-37.

- 110 Shoji T, Tanaka F, Takata T, Yanagihara K, Otake Y, Hanaoka N, Miyahara R, Nakagawa T, Kawano Y, Ishikawa S, Katakura H, Wada H: Clinical significance of p21 expression in non-small-cell lung cancer. J Clin Oncol 2002;20:3865-3871.

11 Dworakowska D, Jassem E, Jassem J, Boltze C, Wiedorn KH, Dworakowski R, Skokowski J, Jaśkiewicz K, Czestochowska E: Absence of prognostic significance of p21(WAF1/CIP1) protein expression in non-small cell lung cancer. Acta Oncol 2005;44:75-79. tic factor in non-small cell lung carcinomas. Pathol Res Pract 2006;202:849-856.

113 Teramen H, Tsukuda K, Tanaka N, Ueno T, Kubo T, Ando M, Soh J, Asano H, Pass HI, Toyooka S, Miyoshi S: Aberrant methylation of p21 gene in lung cancer and malignant pleural mesothelioma. Acta Med Okayama 2011;65:179-184.

114 Fang JY, Lu YY: Effects of histone acetylation and DNA methylation on p21(WAF1) regulation. World J Gastroenterol 2002;8: 400-405.

115 Rosell R, Felip E: Predicting response to paclitaxel/carboplatin-based therapy in nonsmall cell lung cancer. Semin Oncol 2001; 28:37-44.

116 Stordal B, Davey M: Understanding cisplatin resistance using cellular models. IUBMB Life 2007;59:696-699.

- 117 Kartalou M, Essigmann JM: Mechanisms of resistance to cisplatin. Mutat Res 2001; 478:23-43.

118 Wei J, Zhao J, Long M, Han Y, Wang X, Lin F, Ren J, He T, Zhang H: p21WAF1/CIP1 gene transcriptional activation exerts cell growth inhibition and enhances chemosensitivity to cisplatin in lung carcinoma cells. BMC Cancer 2010;10:632.

119 Cheung CT, Hasan MK, Widodo N, Kaul SC, Wadhwa R: CARF: an emerging regulator of p53 tumor suppressor and senescence pathway. Mech Ageing Dev 2009;130:1823.

120 Tsao MS, Aviel-Ronen S, Ding K, Lau D, Liu N, Sakurada A, Whitehead M, Zhu CQ, Livingston R, Johnson DH, Rigas J, Seymour L, Winton T, Shepherd FA: Prognostic and predictive importance of p53 and RAS for adjuvant chemotherapy in nonsmall-cell lung cancer. J Clin Oncol 2007; 25:5240-5247.

121 Hall PA, Lane DP: p53 in tumour pathology: can we trust immunohistochemistry? - Revisited! J Pathol 1994;172:1-4.

122 Greenblatt MS, Bennett WP, Hollstein M, Harris CC: Mutations in the p53 tumor suppressor gene: clues to cancer etiology and molecular pathogenesis. Cancer Res 1994; 54:4855-4878.

123 Mitsudomi T, Hamajima N, Ogawa M, Takahashi T: Prognostic significance of p53 alterations in patients with non-small cell lung cancer: a meta-analysis. Clin Cancer Res 2000;6:4055-4063.

124 Mascaux C, Iannino N, Martin B, Paesmans M, Berghmans T, Dusart M, Haller A, Lothaire P, Meert AP, Noel S, Lafitte JJ, Sculier JP: The role of RAS oncogene in survival of patients with lung cancer: a systematic review of the literature with meta-analysis. Br J Cancer 2005;92:131-139.
125 Steels E, Paesmans M, Berghmans T, Branle F, Lemaitre F, Mascaux C, Meert AP, Vallot F, Lafitte JJ, Sculier JP: Role of p53 as a prognostic factor for survival in lung cancer: a systematic review of the literature with a meta-analysis. Eur Respir J 2001;18: 705-719.

126 Huncharek M, Muscat J, Geschwind JF: K-ras oncogene mutation as a prognostic marker in non-small cell lung cancer: a combined analysis of 881 cases. Carcinogenesis 1999;20:1507-1510.

127 Schiller JH, Adak S, Feins RH, Keller SM, Fry WA, Livingston RB, Hammond ME, Wolf B, Sabatini L, Jett J, Kohman L, Johnson DH: Lack of prognostic significance of p53 and K-ras mutations in primary resected non-small-cell lung cancer on E4592: a laboratory ancillary study on an Eastern Cooperative Oncology Group prospective randomized trial of postoperative adjuvant therapy. J Clin Oncol 2001;19:448-457.

128 Wang YC, Lin RK, Tan YH, Chen JT, Chen CY, Wang YC: Wild-type p53 overexpression and its correlation with MDM2 and p14ARF alterations: an alternative pathway to non-small-cell lung cancer. J Clin Oncol 2005;23:154-164.

129 Brown JM, Wouters BG: Apoptosis, p53, and tumor cell sensitivity to anticancer agents. Cancer Res 1999;59:1391-1399.

130 Lowe SW, Sherr CJ: Tumor suppression by Ink4a-Arf: progress and puzzles. Curr Opin Genet Dev 2003;13:77-83.

131 Sengupta S, Harris CC: p53: traffic cop at the crossroads of DNA repair and recombination. Nat Rev Mol Cell Biol 2005;6:44-55.

132 Olaussen KA, Dunant A, Fouret P, Brambilla E, André F, Haddad V, Taranchon E, Filipits M, Pirker R, Popper HH, Stahel R, Sabatier L, Pignon JP, Tursz T, Le Chevalier T, Soria JC, IALT Bio Investigators: DNA repair by ERCC1 in non-small-cell lung cancer and Cisplatin-based adjuvant chemotherapy. N Engl J Med 2006;355:983991.

133 Mohamed S, Yasufuku K, Hiroshima K, Nakajima T, Yoshida S, Suzuki M, Sekine Y, Shibuya K, Iizasa T, Farouk A, Fujisawa T: Prognostic implications of cell cycle-related proteins in primary resectable pathologic N2 nonsmall cell lung cancer. Cancer 2007;109:2506-2514

134 De Marinis F, Gebbia V, De Petris L: Neoadjuvant chemotherapy for stage IIIA-N2 non-small cell lung cancer. Ann Oncol 2005;16:iv116-iv122.

135 Besson A, Hwang HC, Cicero S, Donovan SL, Gurian-West M, Johnson D, Clurman BE, Dyer MA, Roberts JM: Discovery of an oncogenic activity in p27Kip1 that causes stem cell expansion and a multiple tumor phenotype. Genes Dev 2007;21:1731-1746. 
-136 Catzavelos C, Tsao MS, DeBoer G, Bhattacharya N, Shepherd FA, Slingerland JM: Reduced expression of the cell cycle inhibitor p27Kipl in non-small cell lung carcinoma: a prognostic factor independent of Ras. Cancer Res 1999;59:684-688.

-137 Takahashi S, Kamata Y, Tamo W, Koyanagi M, Hatanaka R, Yamada Y, Tsushima T, Takaya S, Fukuda I: Relationship between postoperative recurrence and expression of cyclin E, p27, and Ki-67 in non-small cell lung cancer without lymph node metastases. Int J Clin Oncol 2002;7:349-355.

138 Pignon J-P, Tribodet H, Scagliotti GV, Douillard J-Y, Shepherd FA, Stephens RJ, Dunant A, Torri V, Rosell R, Seymour L, Spiro SG, Rolland E, Fossati R, Aubert D, Ding K, Waller D, Le Chevalier T, Lung Adjuvant Cisplatin Evaluation (LACE): A pooled analysis of five randomized clinical trials including 4,584 patients. J Clin Oncol 2006; 24:366s (abstr 7008).

139 Filipits M, Pirker R, Dunant A, Lantuejoul S, Schmid K, Huynh A, Haddad V, André F, Stahel R, Pignon JP, Soria JC, Popper $\mathrm{HH}$, Le Chevalier T, Brambilla E: Cell cycle regulators and outcome of adjuvant cisplatin-based chemotherapy in completely resected non-small-cell lung cancer: the International Adjuvant Lung Cancer Trial Biologic Program. J Clin Oncol 2007;25: 2735-2740.

140 St Croix B, Flørenes VA, Rak JW, Flanagan M, Bhattacharya N, Slingerland JM, Kerbel RS: Impact of the cyclin-dependent kinase inhibitor p27Kip1 on resistance of tumor cells to anticancer agents. Nat Med 1996;2: 1204-1210.

141 Tannock I: Cell kinetics and chemotherapy: a critical review. Cancer Treat Rep 1978;62: 1117-1133.

142 Eymin B, Haugg M, Droin N, Sordet O, Dimanche-Boitrel MT, Solary E: p27Kip1 induces drug resistance by preventing apoptosis upstream of cytochrome c release and procaspase- 3 activation in leukemic cells. Oncogene 1999;18:1411-1418.

143 Hashimoto N, Yachida S, Okano K, Wakabayashi H, Imaida K, Kurokohchi K, Masaki T, Kinoshita H, Tominaga M, Ajiki T, Ku Y, Okabayashi T, Hanazaki K, Hiroi M, Izumi S, Mano S, Okada S, Karasawa Y, Maeba T, Suzuki Y: Immunohistochemically detected expression of p27(Kip1) and Skp2 predicts survival in patients with intrahepatic cholangiocarcinomas. Ann Surg Oncol 2009; 16:395-403.

$\checkmark 144$ Pertia A, Nikoleishvili D, Trsintsadze O, Gogokhia N, Managadze L, Chkhotua A: Loss of p27(Kip1) CDKI is a predictor of poor recurrence-free and cancer-specific survival in patients with renal cancer. Int Urol Nephrol 2007;39:381-387.
45 Qi CF, Xiang S, Shin MS, Hao X, Lee CH, Zhou JX, Torrey TA, Hartley JW, Fredrickson TN, Morse HC 3rd: Expression of the cyclin-dependent kinase inhibitor p27 and its deregulation in mouse B cell lymphomas. Leuk Res 2006;30:153-163.

146 Sánchez-Beato M, Camacho FI, MartínezMontero JC, Sáez AI, Villuendas R, Sánchez-Verde L, García JF, Piris MA: Anomalous high p27/KIP1 expression in a subset of aggressive B-cell lymphomas is associated with cyclin D3 overexpression. p27/KIP1cyclin D3 colocalization in tumor cells. Blood 1999;94:765-772.

147 Fredersdorf S, Burns J, Milne AM, Packham G, Fallis L, Gillett CE, Royds JA, Peston D, Hall PA, Hanby AM, Barnes DM, Shousha S, O'Hare MJ, Lu X: High level expression of p27(kipl) and cyclin D1 in some human breast cancer cells: inverse correlation between the expression of p27(kip1) and degree of malignancy in human breast and colorectal cancers. Proc Natl Acad Sci USA 1997;94:6380-6385.

148 Kawamata N, Morosetti R, Miller CW, Park D, Spirin KS, Nakamaki T, Takeuchi S, Hatta Y, Simpson J, Wilcyznski S, Lee YY, Bartram CR, Koeffler HP: Molecular analysis of the cyclin-dependent kinase inhibitor gene p27/Kip1 in human malignancies. Cancer Res 1995;55:2266-2269.

149 Blain SW, Massagué J: Breast cancer banishes p27 from nucleus. Nat Med 2002;8: 1076-1078.

150 Viglietto G, Motti ML, Fusco A: Understanding p27(kip1) deregulation in cancer: down-regulation or mislocalization. Cell Cycle 2002;1:394-400.

151 Pagano M, Tam SW, Theodoras AM, BeerRomero P, Del Sal G, Chau V, Yew PR, Draetta GF, Rolfe M: Role of the ubiquitinproteasome pathway in regulating abundance of the cyclin-dependent kinase inhibitor p27. Science 1995;269:682-685.

152 Sheaff RJ, Groudine M, Gordon M, Roberts JM, Clurman BE: Cyclin E-CDK2 is a regulator of p27Kip1. Genes Dev 1997;11:14641478.

153 Nguyen H, Gitig DM, Koff A: Cell-free degradation of $\mathrm{p} 27$ (kip1), a G1 cyclin-dependent kinase inhibitor, is dependent on CDK2 activity and the proteasome. Mol Cell Biol 1999;19:1190-1201.

154 Montagnoli A, Fiore F, Eytan E, Carrano AC, Draetta GF, Hershko A, Pagano M: Ubiquitination of p27 is regulated by CDKdependent phosphorylation and trimeric complex formation. Genes Dev 1999;13: 1181-1189.

155 Carrano AC, Eytan E, Hershko A, Pagano $\mathrm{M}$ : SKP2 is required for ubiquitin-mediated degradation of the CDK inhibitor p27. Nat Cell Biol 1999;1:193-199.
56 Boehm M, Yoshimoto T, Crook MF, Nallamshetty S, True A, Nabel GJ, Nabel EG: A growth factor-dependent nuclear kinase phosphorylates p27(Kip1) and regulates cell cycle progression. EMBO J 2002;21:33903401.

157 Liang J, Zubovitz J, Petrocelli T, Kotchetkov R, Connor MK, Han K, Lee JH, Ciarallo S, Catzavelos C, Beniston R, Franssen E, Slingerland JM: PKB/Akt phosphorylates p27, impairs nuclear import of p27 and opposes p27-mediated G1 arrest. Nat Med 2002;8:1153-1160.

158 Dijkers PF, Medema RH, Pals C, Banerji L, Thomas NS, Lam EW, Burgering BM, Raaijmakers JA, Lammers JW, Koenderman L, Coffer PJ: Forkhead transcription factor FKHR-L1 modulates cytokine-dependent transcriptional regulation of p27(KIP1). Mol Cell Biol 2000;20:91389148.

159 Medema RH, Kops GJ, Bos JL, Burgering BM: AFX-like Forkhead transcription factors mediate cell-cycle regulation by Ras and PKB through p27kip1. Nature 2000; 404:782-787.

160 Blagosklonny MV: Are p27 and p21 cytoplasmic oncoproteins? Cell Cycle 2002; 1 : 391-393.

161 Bouchard C, Thieke K, Maier A, Saffrich R, Hanley-Hyde J, Ansorge W, Reed S, Sicinski P, Bartek J, Eilers M: Direct induction of cyclin D2 by Myc contributes to cell cycle progression and sequestration of p27. EMBO J 1999;18:5321-5333.

162 Perez-Roger I, Kim SH, Griffiths B, Sewing A, Land H: Cyclins D1 and D2 mediate myc-induced proliferation via sequestration of p27(Kip1) and p21(Cip1). EMBO J 1999;18:5310-5320.

163 Yakes FM, Chinratanalab W, Ritter CA, King W, Seelig S, Arteaga CL: Herceptin-induced inhibition of phosphatidylinositol-3 kinase and Akt is required for antibody-mediated effects on p27, cyclin D1, and antitumor action. Cancer Res 2002;62:4132-4141.

164 Lane HA, Beuvink I, Motoyama AB, Daly JM, Neve RM, Hynes NE: ErbB2 potentiates breast tumor proliferation through modulation of p27(Kip1)-Cdk2 complex formation: receptor overexpression does not determine growth dependency. Mol Cell Biol 2000;20:3210-3223.

165 Slingerland JM, Hengst L, Pan CH, Alexander D, Stampfer MR, Reed SI: A novel inhibitor of cyclin-CDK activity detected in transforming growth factor beta-arrested epithelial cells. Mol Cell Biol 1994;14:36833694.

166 Suzuki A, Kawano H, Hayashida M, Hayasaki Y, Tsutomi Y, Akahane K: Procaspase 3/p21 complex formation to resist Fas-mediated cell death is initiated as a result of the phosphorylation of $\mathrm{p} 21$ by protein kinase A. Cell Death Differ 2000;7:721-728. 
167 Watanabe J, Sato H, Kanai T, Kamata Y, Jobo T, Hata H, Fujisawa T, Ohno E, Kameya T, Kuramoto H: Paradoxical expression of cell cycle inhibitor p27 in endometrioid adenocarcinoma of the uterine corpus - correlation with proliferation and clinicopathological parameters. Br J Cancer 2002;87:81-85.

-168 Singh SP, Lipman J, Goldman H, Ellis FH Jr, Aizenman L, Cangi MG, Signoretti S, Chiaur DS, Pagano M, Loda M: Loss or altered subcellular localization of p27 in Barrett's associated adenocarcinoma. Cancer Res 1998;58:1730-1735.

169 Hidaka T, Hama S, Shrestha P, Saito T, Kajiwara Y, Yamasaki F, Sugiyama K, Kurisu $\mathrm{K}$ : The combination of low cytoplasmic and high nuclear expression of p27 predicts a better prognosis in high-grade astrocytoma. Anticancer Res 2009;29:597-603.

$\checkmark 170$ Pateras IS, Apostolopoulou K, Koutsami M, Evangelou K, Tsantoulis P, Liloglou T, Nikolaidis G, Sigala F, Kittas C, Field JK, Kotsinas A, Gorgoulis VG: Downregulation of the KIP family members p27(KIP1) and p57(KIP2) by SKP2 and the role of methylation in p57(KIP2) inactivation in nonsmall cell lung cancer. Int J Cancer 2006;119:2546-2556.

171 Kobatake T, Yano M, Toyooka S, Tsukuda K, Dote H, Kikuchi T, Toyota M, Ouchida M, Aoe M, Date H, Pass HI, Doihara H, Shimizu N: Aberrant methylation of p57KIP2 gene in lung and breast cancers and malignant mesotheliomas. Oncol Rep 2004;12: 1087-1092.

- 172 Kondo M, Matsuoka S, Uchida K, Osada H, Nagatake M, Takagi K, Harper JW, Takahashi T, Elledge SJ, Takahashi T: Selective maternal-allele loss in human lung cancers of the maternally expressed p57KIP2 gene at 11p15.5. Oncogene 1996;12:1365-1368.

173 Biaoxue R, Xiguang C, Hua L, Hui M, Shuanying Y, Wei Z, Wenli S, Jie D: Decreased expression of decorin and p57(KIP2) correlates with poor survival and lymphatic metastasis in lung cancer patients. Int $J$ Biol Markers 2011;26:9-21.

-174 Wikman H, Nymark P, Väyrynen A, Jarmalaite S, Kallioniemi A, Salmenkivi K, Vainio-Siukola K, Husgafvel-Pursiainen K, Knuutila S, Wolf M, Anttila S: CDK4 is a probable target gene in a novel amplicon at 12q13.3-q14.1 in lung cancer. Genes Chromosomes Cancer 2005;42:193-199.

175 Pentimalli F, Giordano A: Promises and drawbacks of targeting cell cycle kinases in cancer. Discov Med 2009;8:177-180.

176 Shapiro GI: Cyclin-dependent kinase pathways as targets for cancer treatment. J Clin Oncol 2006;24:1770-1783.

177 Malumbres M, Pevarello P, Barbacid M, Bischoff JR: CDK inhibitors in cancer therapy: what is next? Trends Pharmacol Sci 2008;29:16-21.
8 Kodym E, Kodym R, Reis AE, Habib AA, Story MD, Saha D: The small-molecule CDK inhibitor, SNS-032, enhances cellular radiosensitivity in quiescent and hypoxic non-small cell lung cancer cells. Lung Cancer 2009; 66:37-47.

179 Keen N, Taylor S: Aurora-kinase inhibitors as anticancer agents. Nat Rev Cancer 2004; 4:927-936.

180 Jackson JR, Patrick DR, Dar MM, Huang PS: Targeted anti-mitotic therapies: can we improve on tubulin agents? Nat Rev Cancer 2007;7:107-117.

$181 \mathrm{Fu}$ J, Bian M, Jiang Q, Zhang C: Roles of Aurora kinases in mitosis and tumorigenesis. Mol Cancer Res 2007;5:1-10.

182 Tomonaga T, Nomura F: Chromosome instability and kinetochore dysfunction. Histol Histopathol 2007;22:191-197.

$>183$ Xu HT, Ma L, Qi FJ, Liu Y, Yu JH, Dai SD, Zhu JJ, Wang EH: Expression of serine threonine kinase 15 is associated with poor differentiation in lung squamous cell carcinoma and adenocarcinoma. Pathol Int 2006; 56:375-380.

184 Ogawa E, Takenaka K, Katakura H, Adachi M, Otake Y, Toda Y, Kotani H, Manabe T, Wada H, Tanaka F: Perimembrane AuroraA expression is a significant prognostic factor in correlation with proliferative activity in non-small-cell lung cancer (NSCLC). Ann Surg Oncol 2008;15:547-554.

185 Liu Q, Kaneko S, Yang L, Feldman RI, Nicosia SV, Chen J, Cheng JQ: Aurora-A abrogation of p53 DNA binding and transactivation activity by phosphorylation of serine 215. J Biol Chem 2004;279: 52175-52182.

186 Smith SL, Bowers NL, Betticher DC, Gautschi O, Ratschiller D, Hoban PR, Booton R, Santibáñez-Koref MF, Heighway J: Overexpression of aurora B kinase (AURKB) in primary non-small cell lung carcinoma is frequent, generally driven from one allele, and correlates with the level of genetic instability. Br J Cancer 2005;93:719-729.

187 Vischioni B, Oudejans JJ, Vos W, Rodriguez JA, Giaccone G: Frequent overexpression of aurora B kinase, a novel drug target, in nonsmall cell lung carcinoma patients. Mol Cancer Ther 2006;5:2905-2913.

188 Giet R, McLean D, Descamps S, Lee MJ, Raff JW, Prigent C, Glover DM: Drosophila Aurora A kinase is required to localize DTACC to centrosomes and to regulate astral microtubules. J Cell Biol 2002;156:437-451.

189 Hannak E, Kirkham M, Hyman AA, Oegema K: Aurora-A kinase is required for centrosome maturation in Caenorhabditis elegans. J Cell Biol 2001;155:1109-1116.

190 Gizatullin F, Yao Y, Kung V, Harding MW, Loda M, Shapiro GI: The Aurora kinase inhibitor VX-680 induces endoreduplication and apoptosis preferentially in cells with compromised p53-dependent postmitotic checkpoint function. Cancer Res 2006;66: 7668-7677.
191 Hoover RR, Harding MW: Synergistic activity of the aurora kinase inhibitor MK0457 (VX-680) with idarubicin, Ara-C, and inhibitors of BCR-ABL. ASH Annual Meeting Abstracts 2006;108:1384.

192 Yang H, Burke T, Dempsey J, Diaz B, Collins E, Toth J, Beckmann R, Ye X: Mitotic requirement for Aurora A kinase is bypassed in the absence of Aurora B kinase. FEBS Lett 2005;579:3385-3391.

193 Lok W, Klein RQ, Saif MW: Aurora kinase inhibitors as anti-cancer therapy. Anticancer Drugs 2010;21:339-350.

194 Lapenna S, Giordano A: Cell cycle kinases as therapeutic targets for cancer. Nat Rev Drug Discov 2009;8:547-566.

195 Yap TA, Molife LR, Blagden SP, de Bono JS: Targeting cell cycle kinases and kinesins in anticancer drug development. Expert Opin Drug Dis 2007;2:539-560.

196 Wolf G, Elez R, Doermer A, Holtrich U, Ackermann H, Stutte HJ, Altmannsberger HM, Rübsamen-Waigmann H, Strebhardt K: Prognostic significance of polo-like kinase (PLK) expression in non-small cell lung cancer. Oncogene 1997;14:543-549.

197 Holtrich U, Wolf G, Bräuninger A, Karn T, Böhme B, Rübsamen-Waigmann H, Strebhardt K: Induction and down-regulation of PLK, a human serine/threonine kinase expressed in proliferating cells and tumors. Proc Natl Acad Sci USA 1994;91:17361740.

198 Sebastian M, Reck M, Waller CF, Kortsik C, Frickhofen N, Schuler M, Fritsch $H$, Gaschler-Markefski B, Hanft G, Munzert G, von Pawel J: The efficacy and safety of BI 2536, a novel Plk-1 inhibitor, in patients with stage IIIB/IV non-small cell lung cancer who had relapsed after, or failed, chemotherapy: results from an open-label, randomized phase II clinical trial. J Thorac Oncol 2010;5:1060-1067.

199 Sterlacci W, Wolf D, Savic S, Hilbe W, Schmid T, Jamnig H, Fiegl M, Tzankov A: High transforming growth factor $\beta$ expression represents an important prognostic parameter for surgically resected nonsmall cell lung cancer. Hum Pathol 2012;43: 339-349.

200 Sherr CJ: Cancer cell cycles. Science 1996; 274:1672-1677.

201 Siegel PM, Shu W, Cardiff RD, Muller WJ, Massagué J: Transforming growth factor beta signaling impairs Neu-induced mammary tumorigenesis while promoting pulmonary metastasis. Proc Natl Acad Sci USA 2003;100:8430-8435.

202 Mishra L, Shetty K, Tang Y, Stuart A, Byers SW: The role of TGF-beta and Wnt signaling in gastrointestinal stem cells and cancer. Oncogene 2005;24:5775-5789.

203 Hannon GJ, Beach D: p15INK4B is a potential effector of TGF-beta-induced cell cycle arrest. Nature 1994;371:257-261. 
204 Datto MB, Li Y, Panus JF, Howe DJ, Xiong Y, Wang XF: Transforming growth factor beta induces the cyclin-dependent kinase inhibitor p21 through a p53-independent mechanism. Proc Natl Acad Sci USA 1995; 92:5545-5549.

205 Polyak K, Kato JY, Solomon MJ, Sherr CJ, Massague J, Roberts JM, Koff A: p27Kip1, a cyclin-Cdk inhibitor, links transforming growth factor-beta and contact inhibition to cell cycle arrest. Genes Dev 1994;8: 9-22.

-206 Pietenpol JA, Stein RW, Moran E, Yaciuk P, Schlegel R, Lyons RM, Pittelkow MR, Münger K, Howley PM, Moses HL: TGFbeta 1 inhibition of C-myc transcription and growth in keratinocytes is abrogated by viral transforming proteins with $\mathrm{pRB}$ binding domains. Cell 1990;61:777-785.

-207 Laiho M, DeCaprio JA, Ludlow JW, Livingston DM, Massagué J: Growth inhibition by TGF-beta linked to suppression of retinoblastoma protein phosphorylation. Cell 1990;62:175-185.

208 Kim WS, Park C, Jung YS, Kim HS, Han J, Park CH, Kim K, Kim J, Shim YM, Park K: Reduced transforming growth factor-beta type II receptor (TGF-beta RII) expression in adenocarcinoma of the lung. Anticancer Res 1999;19:301-306.

-209 Blobe GC, Schiemann WP, Lodish HF: Role of transforming growth factor beta in human disease. N Engl J Med 2000;342:1350 1358.

210 Elliott RL, Blobe GC: Role of transforming growth factor beta in human cancer. J Clin Oncol 2005;23:2078-2093.

211 Zhang HT, Chen XF, Wang MH, Wang JC, Qi QY, Zhang RM, Xu WQ, Fei QY, Wang F, Cheng QQ, Chen F, Zhu CS, Tao SH, Luo Z: Defective expression of transforming growth factor beta receptor type II is associated with $\mathrm{CpG}$ methylated promoter in primary non-small cell lung cancer. Clin Cancer Res 2004;10:2359-2367.

-212 Anumanthan G, Halder SK, Osada H, Takahashi T, Massion PP, Carbone DP, Datta PK: Restoration of TGF-beta signalling reduces tumorigenicity in human lung cancer cells. Br J Cancer 2005;93:1157-1167.

$\checkmark 213$ Jeon HS, Dracheva T, Yang SH, Meerzaman D, Fukuoka J, Shakoori A, Shilo K, Travis WD, Jen J: SMAD6 contributes to patient survival in non-small cell lung cancer and its knockdown reestablishes TGF-beta homeostasis in lung cancer cells. Cancer Res 2008;68:9686-9692.
214 Martin B, Paesmans M, Mascaux C, Berghmans T, Lothaire P, Meert AP, Lafitte JJ, Sculier JP: Ki-67 expression and patients survival in lung cancer: systematic review of the literature with meta-analysis. $\mathrm{Br}$ J Cancer 2004;91:2018-2025.

215 Sterlacci W, Tzankov A, Veits L, Oberaigner W, Schmid T, Hilbe W, Fiegl M: The prognostic impact of sex on surgically resected non-small cell lung cancer depends on clinicopathologic characteristics. Am J Clin Pathol 2011;135:611-618.

216 Visbal AL, Williams BA, Nichols FC 3rd, Marks RS, Jett JR, Aubry MC, Edell ES, Wampfler JA, Molina JR, Yang P: Gender differences in non-small-cell lung cancer survival: an analysis of 4,618 patients diagnosed between 1997 and 2002. Ann Thorac Surg 2004;78:209-215.

217 Sterlacci W, Savic S, Schmid T, Oberaigner W, Auberger J, Fiegl M, Tzankov A: Tissue sparing application of the newly proposed IASLC/ATS/ERS classification of nonsmall cell lung cancer shows practical diagnostic and prognostic impact. Am J Clin Pathol 2012, in press.

218 George S, Kasimis BS, Cogswell J, Schwarzenberger P, Shapiro GI, Fidias P, Bukowski RM: Phase I study of flavopiridol in combination with paclitaxel and carboplatin in patients with non-small-cell lung cancer. Clin Lung Cancer 2008;9:160-165.

219 Benson C, White J, De Bono J, O’Donnell A, Raynaud F, Cruickshank C, McGrath H, Walton M, Workman P, Kaye S, Cassidy J, Gianella-Borradori A, Judson I, Twelves C: A phase I trial of the selective oral cyclindependent kinase inhibitor seliciclib (CYC202; R-roscovitine), administered twice daily for 7 days every 21 days. $\mathrm{Br}$ J Cancer 2007;96:29-37.

220 Le Tourneau C, Faivre S, Laurence V, Delbaldo C, Vera K, Girre V, Chiao J, Armour S, Frame S, Green SR, Gianella-Borradori A, Diéras V, Raymond E: Phase I evaluation of Seliciclib (R-roscovitine), a novel oral cyclin-dependent kinase inhibitor, in patients with advanced malignancies. Eur J Cancer 2010;46:3243-3250.
221 Cai D, Byth KF, Shapiro GI: AZ703, an imidazo[1,2-a]pyridine inhibitor of cyclindependent kinases 1 and 2, induces E2F-1dependent apoptosis enhanced by depletion of cyclin-dependent kinase 9. Cancer Res 2006;66:435-444.

222 Hoang TM, Favier B, Valette A, Barette C, Nguyen CH, Lafanechère L, Grierson DS, Dimitrov S, Molla A: Benzo[e]pyridoindoles, novel inhibitors of the Aurora kinases. Cell Cycle 2009;8:765-772.

223 Harrington EA, Bebbington D, Moore J, Rasmussen RK, Ajose-Adeogun AO, Nakayama T, Graham JA, Demur C, Hercend T, Diu-Hercend A, Su M, Golec JM, Miller KM: VX-680, a potent and selective smallmolecule inhibitor of the Aurora kinases, suppresses tumor growth in vivo. Nat Med 2004;10:262-267.

224 Plummer E, Calvert H, Arkenau H, Lock V, Squires M, Smith DM, Lewis S, Judson I: A dose-escalation and pharmacodynamic study of AT9283 in patients with refractory solid tumours. J Clin Oncol 2008;26:116s (abstract 2519).

225 Dees EC, Infante JR, Cohen RB, O’Neil BH, Jones S, von Mehren M, Danaee H, Lee Y, Ecsedy J, Manfredi M, Galvin K, Stringer B, Liu H, Eton O, Fingert H, Burris H: Phase 1 study of MLN8054, a selective inhibitor of Aurora A kinase in patients with advanced solid tumors. Cancer Chemother Pharmacol 2011;67:945-954

-226 Schöffski P, Jones SF, Dumez H, Infante JR, Van Mieghem E, Fowst C, Gerletti P, Xu H, Jakubczak JL, English PA, Pierce KJ, Burris HA: Phase I, open-label, multicentre, doseescalation, pharmacokinetic and pharmacodynamic trial of the oral Aurora kinase inhibitor PF-03814735 in advanced solid tumours. Eur J Cancer 2011;47:2256-2264.

227 Wilkinson RW, Odedra R, Heaton SP, Wedge SR, Keen NJ, Crafter C, Foster JR, Brady MC, Bigley A, Brown E, Byth KF, Barrass NC, Mundt KE, Foote KM, Heron NM, Jung FH, Mortlock AA, Boyle FT, Green S: AZD1152, a selective inhibitor of Aurora B kinase, inhibits human tumor xenograft growth by inducing apoptosis. Clin Cancer Res 2007;13:3682-3688.

-228 Hardwicke MA, Oleykowski CA, Plant R, Wang J, Liao Q, Moss K, Newlander K, Adams JL, Dhanak D, Yang J, Lai Z, Sutton D, Patrick D: GSK1070916, a potent Aurora B/C kinase inhibitor with broad antitumor activity in tissue culture cells and human tumor xenograft models. Mol Cancer Ther 2009;8:1808-1817. 